\title{
Metal Speciation in the Upper Arkansas River, Colorado, 1990-93
}

By MELANIE L. CLARK and MICHAEL E. LEWIS

\section{U.S. GEOLOGICAL SURVEY}

Water-Resources Investigations Report 96-4282

Prepared in cooperation with the

CITY OF COLORADO SPRINGS, DEPARTMENT OF UTILITIES;

PUEBLO BOARD OF WATER WORKS;

SOUTHEASTERN COLORADO WATER CONSERVANCY DISTRICT;

PUEBLO COUNTY, DEPARTMENT OF PLANNING AND DEVELOPMENT;

CITY OF AURORA, DEPARTMENT OF UTILITIES;

ST. CHARLES MESA WATER DISTRICT;

UPPER ARKANSAS AREA COUNCIL OF GOVERNMENTS;

UPPER ARKANSAS WATER CONSERVANCY DISTRICT;

CITY OF PUEBLO, DEPARTMENT OF UTILITIES;

PUEBLO WEST METROPOLITAN DISTRICT;

FREMONT SANITATION DISTRICT;

CITY OF ROCKY FORD, CITY OF LAS ANIMAS, and the CITY OF LAMAR

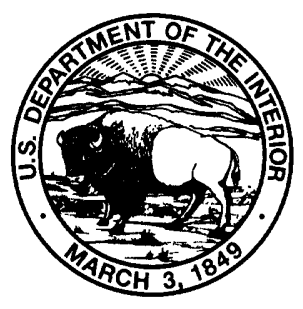




\section{U.S. DEPARTMENT OF THE INTERIOR BRUCE BABBITT, Secretary}

U.S. GEOLOGICAL SURVEY

Gordon P. Eaton, Director

The use of firm, trade, and brand names in this report is for identification purposes only and does not constitute endorsement by the U.S. Geological Survey.

For additional information write to:

Copies of this report can be purchased from:

District Chief

U.S. Geological Survey

Box 25046, Mail Stop 415

Denver Federal Center

Denver, CO 80225-0046
U.S. Geological Survey

Branch of Information Services

Box 25286

Denver, CO 80225-0286 


\section{CONTENTS}

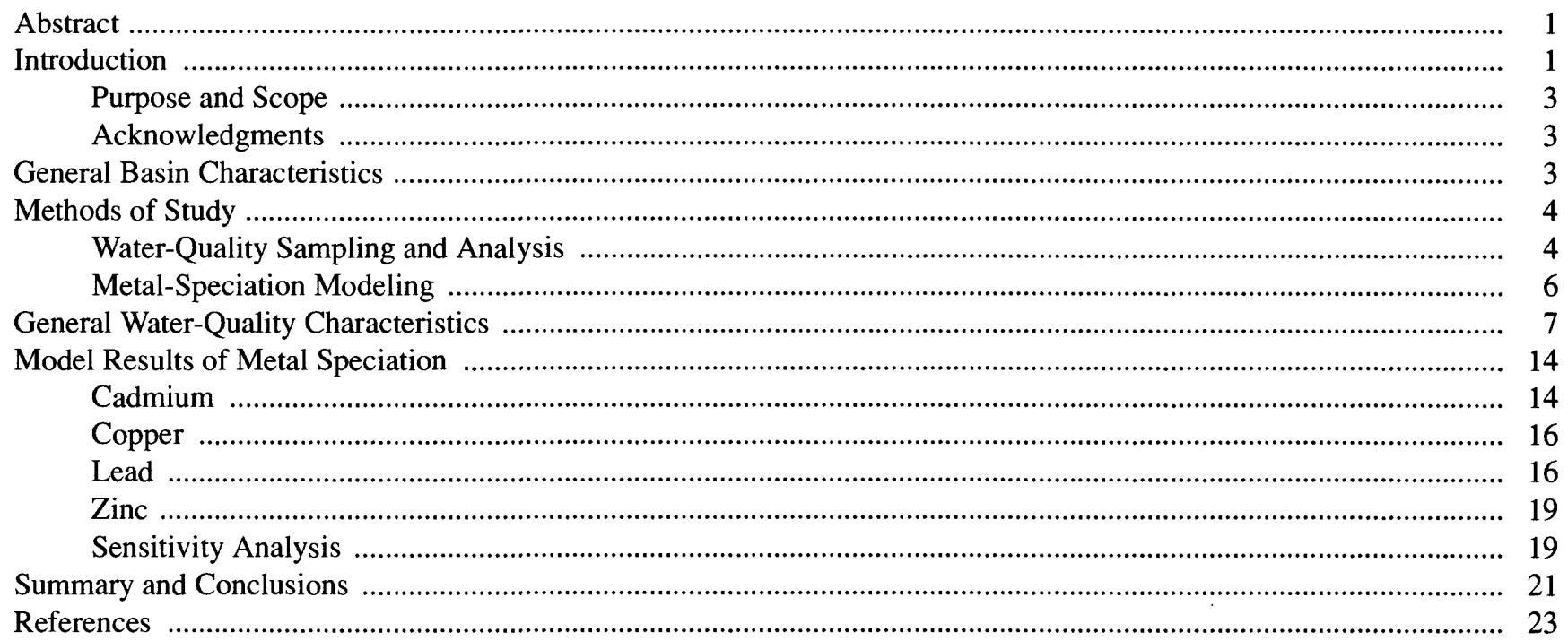

\section{FIGURES}

1. Map showing location of the study area and sampling sites.

2-9. Graphs showing:

2. Seasonal flow-duration curves, April 1990-March 1993

3. Median concentrations of major ions, April 1990-March 1993

4. Median concentrations of total-recoverable metals by sampling site and streamflow regime, April 1990-March 1993

5. Median concentrations of dissolved metals by sampling site and streamflow regime, April 1990-March 1993.

6. Median concentrations of dissolved-cadmium species and alkalinity by sampling site and streamflow regime, April 1990-March 1993.

7. Median concentrations of dissolved-copper species and alkalinity by sampling site and streamflow regime, April 1990-March 1993

8. Median concentrations of dissolved-lead species and alkalinity by sampling site and streamflow regime, April 1990-March 1993

9. Median concentrations of dissolved-zinc species and alkalinity by sampling site and streamflow regime, April 1990-March 1993

\section{TABLES}

1. Water-quality sampling sites

2. Statistical summary of total-recoverable and dissolved-metal concentrations in the upper Arkansas River, April 1990 through March 1993

3. Model-calculated dissolved-metal species listed in descending order of predominance 14 
CONVERSION FACTORS, ABBREVIATIONS, AND VERTICAL DATUM

\begin{tabular}{rcl}
\hline Multiply & By & To obtain \\
\hline cubic foot per second $\left(\mathrm{ft}^{3} / \mathrm{s}\right)$ & 0.02832 & cubic meter per second \\
foot $(\mathrm{ft})$ & 0.3048 & meter \\
inch & 25.4 & millimeter \\
mile $(\mathrm{mi})$ & 1.609 & kilometer \\
square mile $\left(\mathrm{mi}^{2}\right)$ & 2.590 & square kilometer \\
\hline
\end{tabular}

Abbreviated water-quality units used in this report:

micrograms per liter $(\mu \mathrm{g} / \mathrm{L})$

micrometer $(\mu \mathrm{m})$

milligrams per liter $(\mathrm{mg} / \mathrm{L})$

nanometer $(\mathrm{nm})$

square meters per gram $\left(\mathrm{m}^{2} / \mathrm{g}\right)$

Sea level: In this report, "sea level" refers to the National Geodetic Vertical Datum of 1929 (NGVD of 1929) - a geodetic datum derived from a general adjustment of the first-order level nets of both the United States and Canada, formerly called Sea Level Datum of 1929. 


\title{
Metal Speciation in the Upper Arkansas River, Colorado, 1990-93
}

\author{
By Melanie L. Clark and Michael E. Lewis
}

Abstract

The upper Arkansas River Basin is a highaltitude, semiarid basin that extends from Leadville to Pueblo, Colorado. Historic mining activity in the basin has substantially degraded water quality in the upper Arkansas River. Water flowing through the numerous abandoned mines and tailings piles in the basin has contributed high concentrations of cadmium, copper, iron, manganese, and zinc to the river. Metal concentrations in the river tend to vary spatially and temporally, largely owing to the effect of streamflow regime and streamflow sources. Elevated concentrations of metals in the Arkansas River are paralleled by high concentrations in the biota. Elevated concentrations of cadmium, copper, and zinc might be one cause for an increase in the mortality rate of brown trout. The bioavailability and toxicity of metals to aquatic life vary with the speciation of the dissolved metals. The free-metal ions, compared to dissolved-metal complexes, generally are the more bioavailable and toxic metal species. The geochemical speciation model MINTEQA2 was used to evaluate the spatial and temporal variability of dissolved-metal speciation in the upper Arkansas River.

Model results of 1990-93 conditions at eight main-stem sites between Leadville and Portland indicate that dissolved copper and lead occurred primarily as hydroxide and carbonate complexes, respectively, at all sites during all streamflow regimes. Conversely, about 50 percent of the dissolved cadmium and zinc, on average, occurred as the free-metal ions, $\mathrm{Cd}^{+2}$ and $\mathrm{Zn}^{+2}$. The highest percentage of dissolved cadmium and zinc concentrations represented by their free-metal ions occurred during the peaksnowmelt runoff flow regime, a period when alkalinity and $\mathrm{pH}$ are lowest in the river. As a result, cadmium and zinc probably are more available for uptake by aquatic life during this period. The maximum percentages of $\mathrm{Cd}^{+2}$ and $\mathrm{Zn}^{+2}$ were at Granite and Buena Vista, two sites immediately downstream from the confluence of Lake Creek with the Arkansas River. Low ionicstrength water is imported into the Arkansas River from the Colorado River Basin through Lake Creek and contributes to less cadmium and zinc complexation at these sites than at other sites. At Buena Vista, about 68 percent of the dissolved cadmium and about 70 percent of the dissolved zinc occurred as their respective free-metal ions. The high percentage of the free-metal ions and the potential implication to aquatic-life toxicity at Granite and Buena Vista are offset by the dilutional effects of Lake Creek, which generally contains metal concentrations that are substantially lower than those in the Arkansas River.

\section{INTRODUCTION}

The upper Arkansas River Basin is a highaltitude, semiarid basin that extends from Leadville to Pueblo, Colorado (fig. 1). Historic mining of sulfideore deposits in the upper basin near Leadville, Colorado, has yielded economic quantities of copper, gold, iron, lead, silver, and zinc (Tweto, 1968) and also has substantially degraded water quality in the upper basin. Water flowing through the numerous abandoned mines and tailings piles in the area has contributed high concentrations of cadmium, copper, iron, manganese, and zinc to the upper Arkansas River 


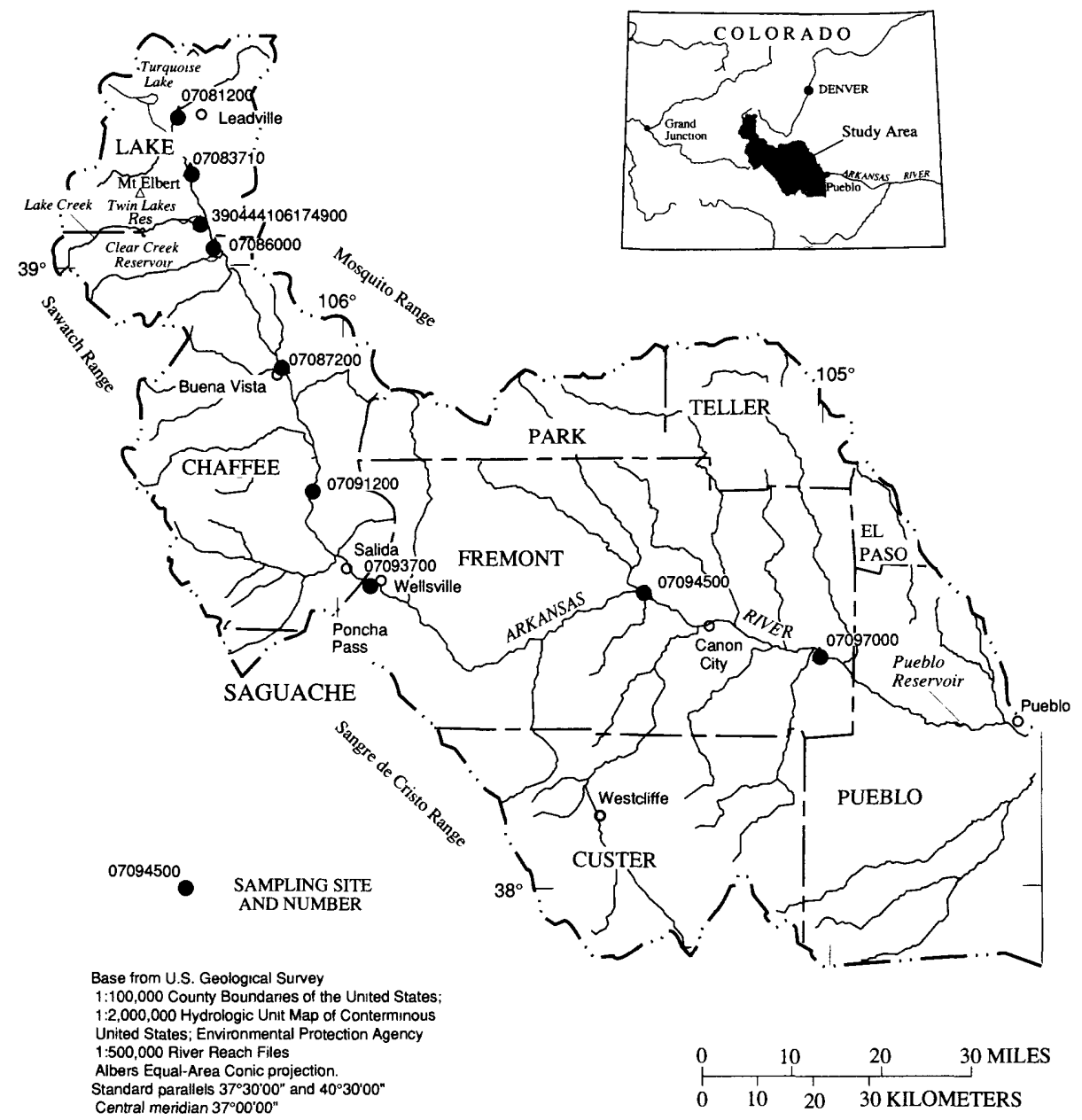

Figure 1. Location of the study area and sampling sites.

(Moran and Wentz, 1974; Wentz, 1974). Metal concentrations in the river vary spatially and temporally, largely owing to the effect of streamflow regime and streamflow sources. Streamflow is derived primarily from snowmelt in the mountains that border the basin, but the natural streamflow of the river is supplemented by transmountain diversions of water from the Colorado River Basin.

Elevated concentrations of metals in the Arkansas River are paralleled by high concentrations in the biota, including macroinvertebrates (Kiffney and Clements, 1993). Elevated concentrations of cadmium, copper, and zinc might be one cause for an increase in the mortality rate of brown trout (U.S. Fish and Wildlife Service, 1993). Dissolved cadmium, copper, lead, and zinc are metals of concern because of their acute and chronic toxicity to aquatic life
(U.S. Environmental Protection Agency, 1986). The uptake of metals from the dissolved phase of the water column generally is the most toxic pathway for aquatic life (Gerhardt, 1993). Bioavailability and toxicity of many metals is inversely proportional to $\mathrm{pH}$ and alkalinity; $\mathrm{pH}$ and alkalinity affect the speciation of dissolved metals between the free-metal ions, which are generally considered to be the more toxic species (Gerhardt, 1993; Borgmann, 1983), and less toxic dissolved-metal complexes. The $\mathrm{pH}$ and alkalinity of the Arkansas River vary as a function of streamflow regime and streamflow sources (Kimball and others, 1995; Crouch and others, 1984); therefore, metal bioavailability and toxicity to aquatic life can vary with streamflow. The $\mathrm{pH}$ and alkalinity of the Arkansas River are lowest during snowmelt runoff and highest during low flow. Water imported into the 
basin through transmountain diversions from the Colorado River Basin might increase metal toxicity in the Arkansas River, because the imported water has lower $\mathrm{pH}$, hardness, and alkalinity than the native water (U.S. Fish and Wildlife Service, 1993).

Unfortunately, an analysis of dissolved-metal species concentrations is not routinely possible in most sampling programs, and metal concentrations generally are reported as dissolved (filtered) or as total-recoverable (not filtered) metals. Although aquatic-life standards for metals generally are based on dissolved-metal concentrations, dissolved metals, as currently analyzed, contain both dissolved freemetal ions and dissolved-metal complexes. Chemicalequilibrium models are available that calculate effective concentrations of free-metal ions and complexed metal species on the basis of physical parameters and dissolved aqueous components. Chemical-equilibrium models have been used successfully in studies to interpret metal speciation in surface waters affected by acid mine drainage (Nordstrom, 1991; Smith and others, 1991).

Beginning in 1990, a study was done by the U.S. Geological Survey, in cooperation with several local agencies, to evaluate the effects of streamflow regime on dissolved-metal speciation in the upper Arkansas River. This evaluation is needed for water managers to more accurately assess the relative bioavailability and potential toxicity of these metals to aquatic organisms in the upper Arkansas River. The study was conducted in cooperation with the City of Colorado Springs, Department of Utilities; Pueblo Board of Water Works; Southeastern Colorado Water Conservancy District; Pueblo County, Department of Planning and Development; City of Aurora, Department of Utilities; St. Charles Mesa Water District; Upper Arkansas Area Council of Governments; Upper Arkansas Water Conservancy District; City of Pueblo, Department of Utilities; Pueblo West Metropolitan District; Fremont Sanitation District; and the Cities of Rocky Ford, Las Animas, and Lamar.

\section{Purpose and Scope}

This report describes the spatial and temporal distributions of dissolved-metal species on the basis of the results of chemical-speciation modeling. This information is used to assess the effect of streamflow regime on dissolved-metal speciation in the upper
Arkansas River. Water-quality data collected from April 1990 through March 1993 at eight main-stem Arkansas River sites were used in the analyses.

\section{Acknowledgments}

The authors gratefully acknowledge the assistance of the many government and local agencies that cooperated with the U.S. Geological Survey to develop this study. The authors express appreciation to Dr. John Stednick, Colorado State University, for providing technical assistance. Special thanks are extended to Briant A. Kimball, Katherine Walton-Day, Robert L. Runkel, and Kathleen S. Smith of the U.S. Geological Survey for their technical guidance in the speciation modeling.

\section{GENERAL BASIN CHARACTERISTICS}

The Arkansas River Basin drains about onefourth of the State of Colorado. The 4,670- $\mathrm{mi}^{2}$ upper Arkansas River Basin includes the 136.7-mi river reach from the headwaters near Leadville to Portland (fig. 1). The Sawatch and Sangre de Cristo Ranges form the western and southern boundaries, and the Mosquito Range forms the eastern and northern boundaries of the study area. Elevations within the study area range from 14,433 ft at Mount Elbert, the highest peak in Colorado, to about 4,670 ft at Pueblo. The mountain ranges are composed of sedimentary rocks of Paleozoic age and igneous and metamorphic rocks principally of Precambrian age. The mineral deposits are of Tertiary age and occur as vein and replacement deposits in Paleozoic and younger rocks.

Precipitation and transmountain diversions are the principal sources of water in the basin. The average annual precipitation varies areally from more than 40 inches to less than 10 inches, generally decreasing with decreasing elevation. Precipitation in the mountains produces a deep snowpack during the winter; snowmelt supplies a high percentage of the total annual streamflow. Transmountain diversions of water from the Colorado River Basin are supplied from several sources located high in the basin. Much of this water is routed to Twin Lakes Reservoir (fig. 1) through closed conduit and open channel flow (Abbott, 1985). The transmountain water is stored in Twin Lakes Reservoir and released to meet 
downstream irrigation and municipal-supply demands. During the study period, April 1990 through March 1993, the mean monthly discharge of the Arkansas River ranged from $70 \mathrm{ft}^{3} / \mathrm{s}$ at Leadville to $688 \mathrm{ft}^{3} / \mathrm{s}$ at Parkdale. The largest source of tributary inflow to the river is water released from Twin Lakes Reservoir into Lake Creek. The mean monthly reservoir release from Twin Lakes Reservoir to Lake Creek and the Arkansas River was $284 \mathrm{ft}^{3} / \mathrm{s}$. Reservoir releases represented about 50 percent of the annual flow in the Arkansas River at Granite, just downstream from the confluence with Lake Creek, and about 30 percent of the total annual flow at Portland. The other tributaries in the basin contribute substantially less flow.

Streamflow in the upper Arkansas River exhibits large temporal variability and can be separated into four distinct streamflow regimes: low flow (October-March), early-snowmelt runoff (April), peak-snowmelt runoff (May-June), and postsnowmelt runoff (July-September) (fig. 2). During the low-flow period in October through March, streamflow is relatively small and is maintained by natural baseflow and reservoir releases. During earlysnowmelt runoff in April, reservoir releases decrease slightly and snowmelt runoff commences. During peak-snowmelt runoff in May and June, streamflow is at its annual maximum and increases substantially in the downstream direction because of reservoir releases and tributary inflow. The post-snowmelt runoff period in July through September includes the receding limb of the snowmelt-runoff hydrograph in July and a period dominated by releases of stored water from Twin Lakes Reservoir in August and September. The effects of tributary contributions from Lake Creek are clearly visible during all four flow regimes, as indicated by the flow-duration curves for Lake Creek and the Arkansas River near Leadville and at Granite (fig. 2).

\section{METHODS OF STUDY}

\section{Water-Quality Sampling and Analysis}

Water-quality samples were collected and analyzed for dissolved and total-recoverable metals and major ions at eight sites on the Arkansas River between Leadville and Portland from April 1990 through March 1993 (table 1). Water-quality samples were collected and analyzed for dissolved and totalrecoverable metals at Lake Creek below Twin Lakes Reservoir (table 1), a major tributary to the Arkansas River that is located $2.8 \mathrm{mi}$ upstream from Granite. A complete description of sampling methods and analytical techniques, in addition to all the water-quality data collected as part of the study, are presented in Dash and Ortiz (1996). Samples were collected throughout the study period during all four streamflow regimes. Samples generally were collected in a downstream order with sample collection corresponding to waterparcel traveltimes. Water-parcel traveltimes were estimated with stream velocities. Onsite measurements included instantaneous streamflow, $\mathrm{pH}$, specific conductance, dissolved oxygen, and water temperature. Field portable meters were used for onsite chemistry measurements of $\mathrm{pH}$, specific conductance, and dissolved oxygen. Water samples were collected, preserved, and analyzed according to U.S. Geological Survey standardized guidelines and quality-control procedures for surface-water samples for the determination of inorganic compounds in filtered water (Sylvester and others, 1990; Ward and Harr, 1990). Water-chemistry samples generally were collected using depth-integrated sampling techniques.

Before each field trip, standard cleaning and rinsing procedures were followed to prepare equipment for sampling. This included cleaning with non-phosphate laboratory detergent, followed by three tap-water rinses, a rinse with dilute 1-percent hydrochloric acid, and three deionized-water rinses. At the sampling site, prior to sample collection, the equipment was rinsed once with deionized water and once with dilute hydrochloric acid, followed by three deionized-water rinses. Finally, equipment was rinsed three times with native streamwater (Dash and Ortiz, 1996).

In this report, dissolved is operationally defined as less than $0.45 \mu \mathrm{m}$ because sample collection for dissolved cations, including trace metals, included filtering water onsite using a standard $0.45-\mu \mathrm{m}$ filter. Kimball and others (1995) reported that colloids (solids with effective diameters that range from $1 \mu \mathrm{m}$ to $1 \mathrm{~nm}$ ) might pass through the $0.45-\mu \mathrm{m}$ filter; thus, trace-element concentrations reported as dissolved in this report might include a substantial percentage of colloidal-size particles. Samples analyzed for totalrecoverable and dissolved cations, including trace metals, were acidified onsite with nitric acid. Samples 

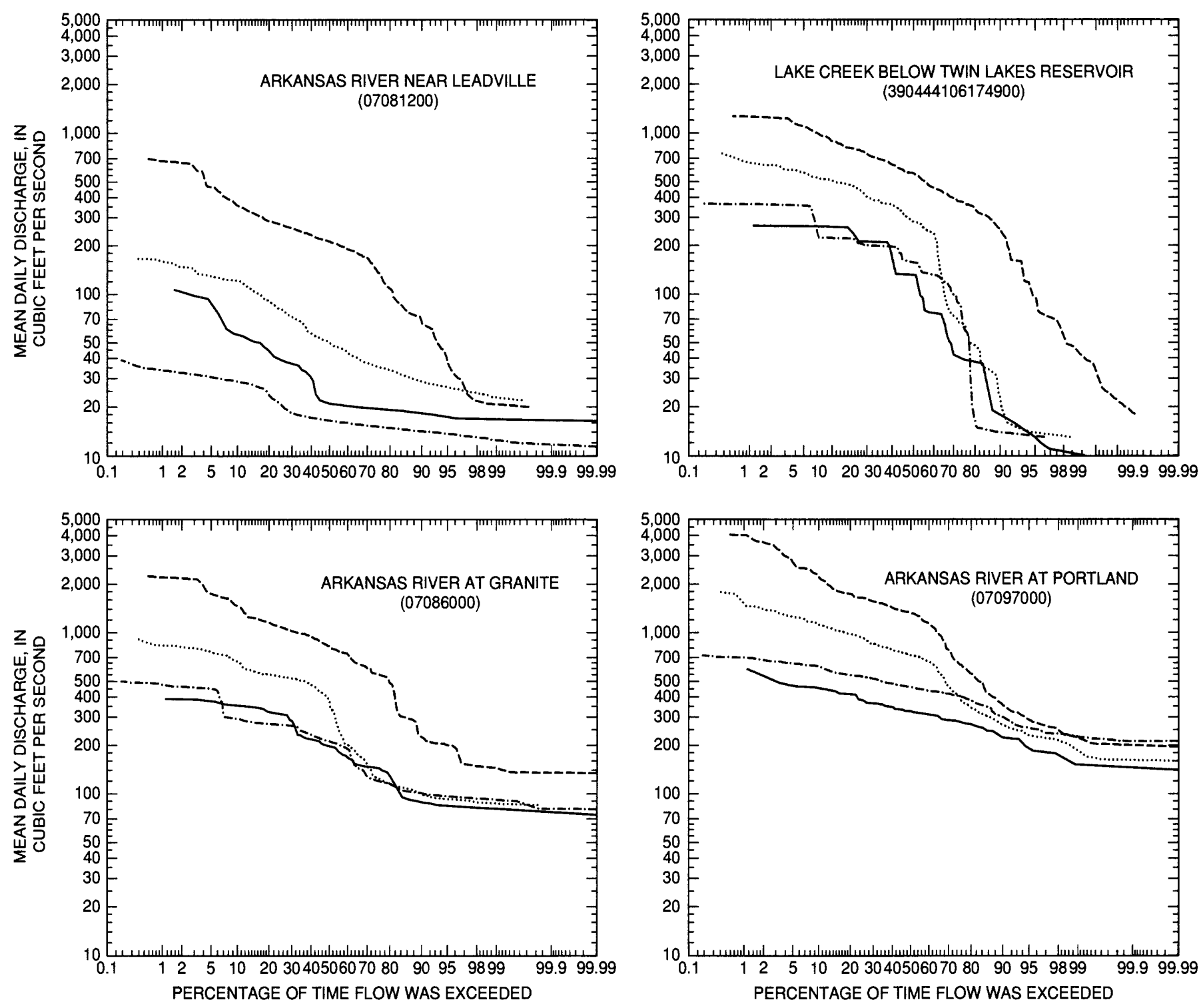

\section{EXPLANATION}

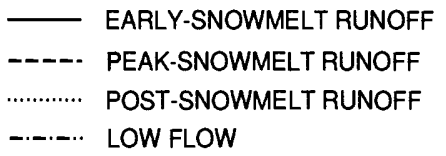

Figure 2. Seasonal flow-duration curves, April 1990-March 1993. 
Table 1. Water-quality sampling sites

\begin{tabular}{llc}
\hline \multicolumn{1}{c}{ Site name and number } & \multicolumn{1}{c}{$\begin{array}{c}\text { Site name used } \\
\text { in report }\end{array}$} & $\begin{array}{c}\text { Distance downstream from } \\
\text { Arkansas River near } \\
\text { Leadville site, in miles }\end{array}$ \\
\hline Arkansas River near Leadville (07081200) & Leadville & 0 \\
Arkansas River below Empire Gulch $(07083710)$ & Empire Gulch & 8.5 \\
Lake Creek below Twin Lakes Reservoir (390444106174900) & Lake Creek & 15.3 \\
Arkansas River at Granite (07086000) & Granite & 18.1 \\
Arkansas River at Buena Vista (07087200) & Buena Vista & 35.6 \\
Arkansas River near Nathrop (07091200) & Nathrop & 51.9 \\
Arkansas River near Wellsville (07093700) & Wellsville & 69.1 \\
Arkansas River at Parkdale (07094500) & Parkdale & 112.4 \\
Arkansas River at Portland (07097000) & Portland & 136.7 \\
\hline
\end{tabular}

analyzed for anions were filtered onsite using a $0.45-\mu \mathrm{m}$ filter. Alkalinity samples were not filtered.

All samples were analyzed by the U.S. Geological Survey's National Water-Quality Laboratory in Arvada, Colorado. Dissolved constituents were analyzed using methods described by Fishman and Friedman (1989) and Fishman (1993). Dissolved calcium, iron, magnesium, sodium, manganese, and zinc were analyzed using atomic emission spectrometry, inductively coupled plasma. Dissolved cadmium, copper, and lead were analyzed using atomic absorption spectrometry in conjunction with a graphite furnace containing a graphite platform. Dissolved sulfate and chloride were analyzed using ion-exchange chromatography. Alkalinity was determined using electrometric titration using a standard solution of a strong acid to a fixed-endpoint of pH 4.5 (Fishman and Friedman, 1989).

A total of 207 environmental samples were analyzed for this study-26 samples from each site, except Nathrop, which had 25 samples. In addition to environmental samples, quality-control samples, including field-equipment blanks, were collected using protocols described in Dash and Ortiz (1996). During the analysis of quality-assurance data, elevated copper concentrations were detected in the field-equipment blanks that were collected with a D-74 non-solenoid, brass sampler. The D-74 sampler primarily was used in June during the peak-snowmelt runoff period. As a result, the copper concentrations for the environmental samples collected with the D-74 sampler are not included in this report.

\section{Metal-Speciation Modeling}

Species distribution of dissolved cadmium, copper, lead, and zinc in samples collected from the Arkansas River was determined using the geochemical speciation model MINTEQA2 (Allison and others, 1991). MINTEQA2 uses simultaneous solution of the nonlinear mass-action expressions and linear massbalance relations to predict the thermodynamic properties of electrolyte solutions. Successive approximations and nested iterations are performed using equilibrium constants to converge on solution properties. For large, complex systems, like the Arkansas River, the equilibrium constant approach is the preferred modeling approach (Nordstrom and others, 1979). An initial estimate of the concentration of each component is made to calculate the concentration of each species according to mass-action expressions written in terms of component concentrations; the total mass of each component is then calculated from the concentrations of every species containing that component. The calculated total mass for each component is then compared with the known input for total mass for each component. If the calculated total mass and the known input total mass differ by more than a preset tolerance level, then a new estimate of the component concentration is made, and the entire procedure is repeated (Allison and others, 1991).

The use of chemical-equilibrium models requires certain assumptions to be made about the modeled system. The measured field constituents of temperature and $\mathrm{pH}$ were used to describe equilibrium field conditions. The oxidation/reduction ion pair of $\mathrm{Fe}(\mathrm{III}) / \mathrm{Fe}$ (II) was entered as the redox couple that is 
most likely to exist in oxidized natural waters with nearly neutral $\mathrm{pH}$, based on pe-pH diagrams (Stumm and Morgan, 1981). All initial dissolved-iron concentrations were assumed to be $\mathrm{Fe}$ (III) based on high dissolved-oxygen concentrations measured during sample collection. Ferrihydrite $\left[\mathrm{Fe}(\mathrm{OH})_{3}\right]$ was allowed to precipitate as a possible solid phase, based on initial model runs where ferrihydrite was determined to have a positive saturation index. Dissolved-metal concentrations less than the minimum reporting level were assigned values of twothirds the reporting level. Inorganic carbon concentration was defined using laboratory alkalinity concentrations. MINTEQA2 does not account for organic substrates.

\section{GENERAL WATER-QUALITY CHARACTERISTICS}

The general water quality of the upper Arkansas River is affected by many factors such as ground- water inflow, direct runoff from snowmelt or rainfall, mine drainage, transmountain diversions, and water use within the basin. These factors are reflected in the physical and chemical properties of the upper

Arkansas River. For the eight main-stem sites on the upper Arkansas River, $\mathrm{pH}$ generally ranged from 7.5 to $8.5 ; \mathrm{pH}$ tended to increase downstream. Alkalinity ranged from as low as 20 to $30 \mathrm{mg} / \mathrm{L}$ as $\mathrm{CaCO}_{3}$ in the upper reaches of the basin to about $170 \mathrm{mg} / \mathrm{L}$ near Portland. The lowest alkalinity values were at Granite and were a result of low-alkalinity inflow from Lake Creek. Wetherbee and others (1991) reported that alkalinity values in Lake Creek below Twin Lakes Reservoir were generally less than $20 \mathrm{mg} / \mathrm{L}$ as $\mathrm{CaCO}_{3}$. Dissolved-oxygen concentrations generally were near saturation throughout the basin.

Throughout the upper basin, water in the Arkansas River was a calcium bicarbonate water type, although the concentrations of the major ions tended to vary spatially (fig. 3). Dissolved-solids concentrations were lowest in the upper reaches of the basin

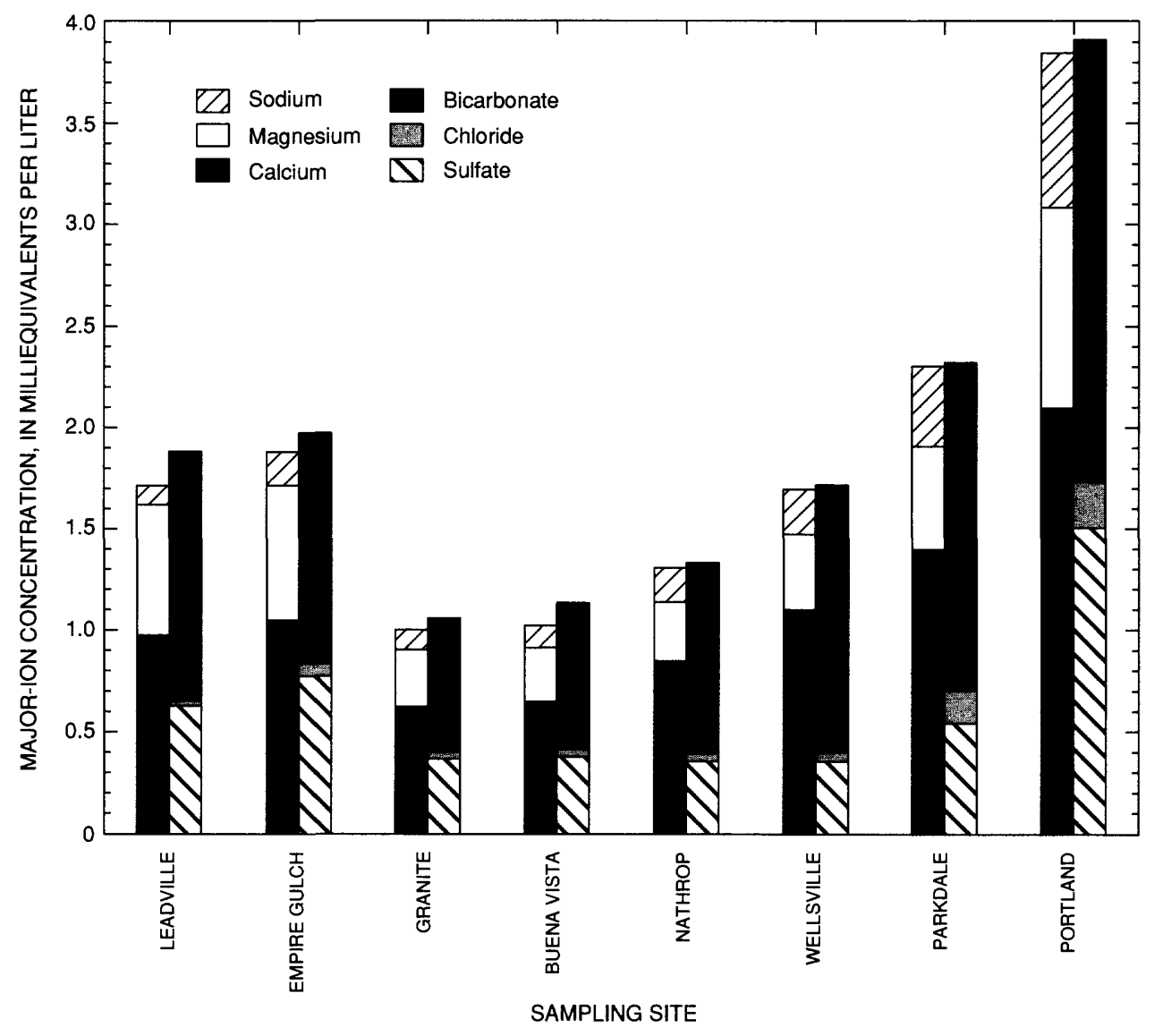

Figure 3. Median concentrations of major ions, April 1990-March 1993. 
because of the predominance of chemically resistant igneous and metamorphic rocks. Calcium and bicarbonate concentrations decreased about 40 percent between Empire Gulch and Granite owing to dilution by inflow from Lake Creek. Water samples that were collected from Lake Creek, as part of this study, were not analyzed for major-ion concentrations, but a review of historical major-ion data for the Lake Creek site indicates that the water was a calcium bicarbonate type. The dissolved-solids concentration in Lake Creek below Twin Lakes Reservoir was typically less than one-half of the dissolved-solids concentration in the Arkansas River below Empire Gulch (Dash and Ortiz, 1996). Dissolved-solids concentrations tended to increase downstream from Granite because of the increased proportion of less chemically resistant sedimentary rocks in the tributary drainages. The chemistry of inflows from tributaries downstream from Salida is strongly influenced by the weathering of shale that contributes calcium, sodium, and sulfate (Kimball and others, 1995).

The primary cause of elevated metal concentrations in the upper Arkansas River is metal-laden drainage from abandoned mines and mine tailings (Moran and Wentz, 1974; Wentz, 1974). The most substantial sources of historical loading of metals to the Arkansas River are located in the Leadville area and include the Leadville Mine Drainage Tunnel and the Yak Tunnel (Moran and Wentz, 1974; Wentz, 1974; Bunting, 1989; Clements, 1991). Since 1992, two water-treatment facilities have operated on the two mine-drainage tunnels. Saint Kevin Gulch and nonpoint sources, including placer deposits along the river alluvium, have been identified as current contributors of metals to the Arkansas River (Kimball and Wetherbee, 1989; Ranville and others, 1989).

During the study period, concentrations of totalrecoverable and dissolved metals varied spatially and temporally (figs. 4 and 5). Total-recoverable metal concentrations, with the exception of total-recoverable cadmium, increased between Leadville and Empire Gulch during all seasonal flow regimes, owing to mine drainage. Total-recoverable cadmium concentrations increased substantially between Leadville and Empire Gulch during early-snowmelt and peak-snowmelt runoff. During low flow and post-snowmelt runoff, concentrations of total-recoverable cadmium concentrations exhibited no discernible spatial variability because concentrations were usually less than the detection level $(1 \mu \mathrm{g} / \mathrm{L})$. Between Empire Gulch and
Granite, concentrations of most total-recoverable metals decreased largely because of dilution by Lake Creek. Kimball and others (1995) also identified sedimentation of aggregated colloids to the streambed as occurring downstream from mine-drainage sources. Total-recoverable copper concentrations, however, increased between Empire Gulch and Granite during early-snowmelt and peak-snowmelt runoff. Totalrecoverable metal concentrations tended to peak at Empire Gulch during all flow regimes except peaksnowmelt runoff.

Total-recoverable metal concentrations generally increased during peak-snowmelt runoff downstream from Granite because of increased partitioning of metals from the dissolved phase to the particulate phase and the resuspension of metal-laden sediment (Kimball and others, 1995). Totalrecoverable metal concentrations in the Arkansas River vary proportionally with suspended-sediment concentrations, which increase with increasing streamflow (Lewis and Edelmann, 1994). Stream velocities during peak-snowmelt runoff generally are quite large and resuspend and transport substantial amounts of metal-laden sediment, whereas during the other three flow regimes, velocities generally are smaller and less capable of transporting substantial suspended material. A statistical summary of all metal-concentration data collected at the eight main-stem sites is presented in table 2. Metal concentrations less than the reporting level were assigned values of two-thirds times the reporting level for the purpose of estimating the mean and median concentrations, which is reflective of the estimation method used for discrete-sample metal concentrations that were input into the model.

Solely based on the magnitude of concentrations, dissolved metals fell into two groups:

(1) dissolved iron, manganese, and zinc-median concentrations ranged up to hundreds of micrograms per liter; and (2) dissolved cadmium, copper, and lead-median concentrations were less than $5 \mu \mathrm{g} / \mathrm{L}$. However, based on spatial and temporal patterns, dissolved cadmium, manganese, and zinc behaved similarly (fig. 5). During most flow regimes, dissolved cadmium, manganese, and zinc concentrations generally were highest at Empire Gulch and decreased downstream owing to dilution by Lake Creek. Increased partitioning to the particulate phase also occurs in the downstream direction (Kimball and others, 1995). The highest concentrations of dissolved cadmium, manganese, and zinc tended to occur during 

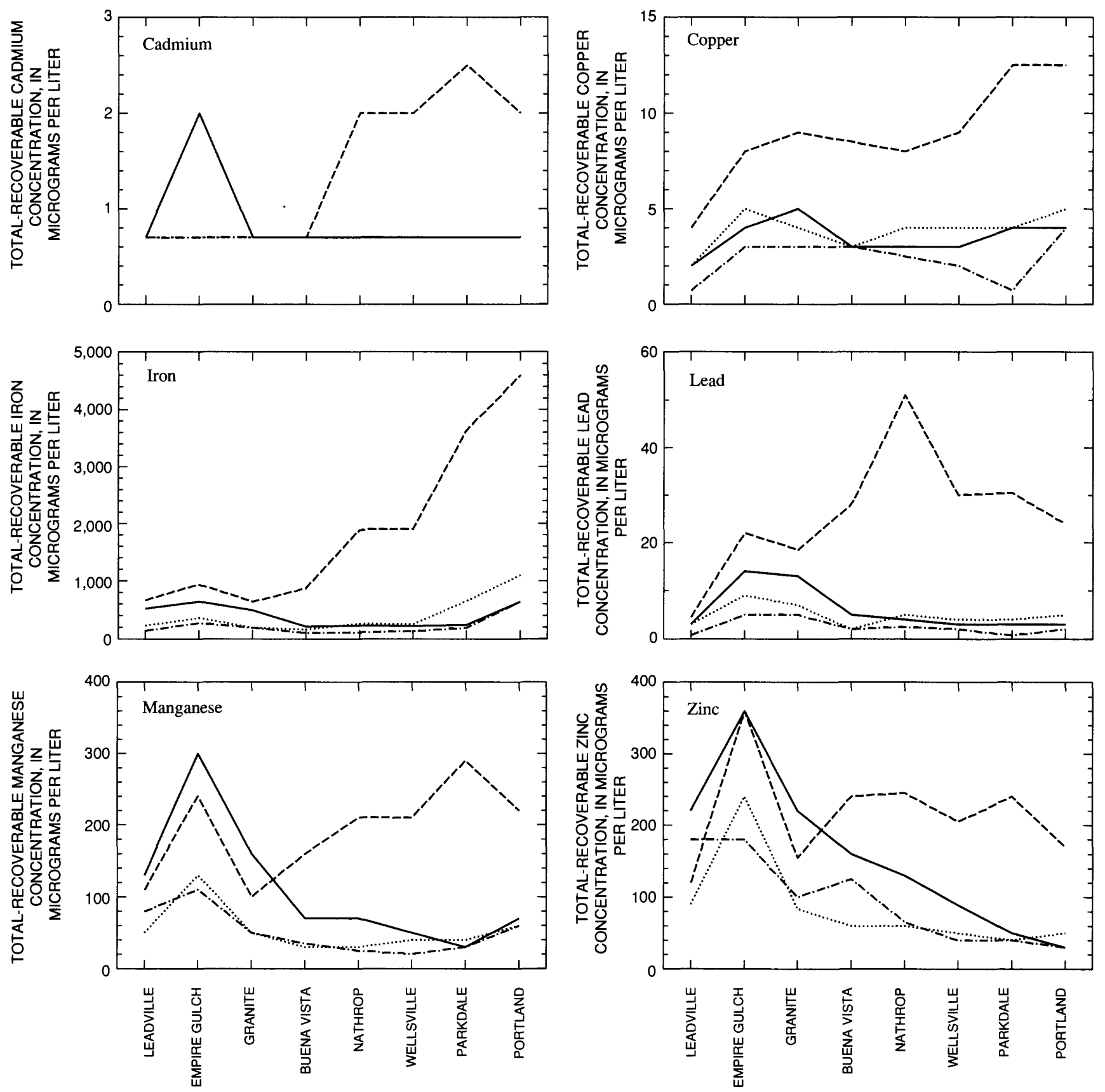

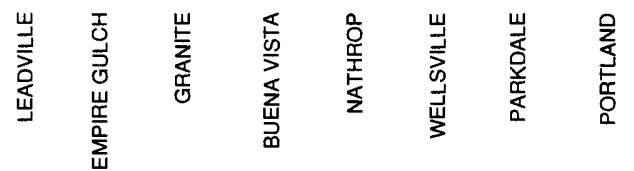

\section{EXPLANATION}

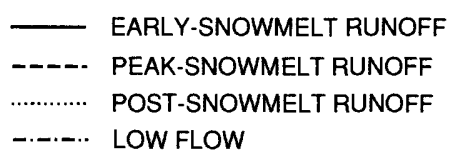

Figure 4. Median concentrations of total-recoverable metals by sampling site and streamflow regime, April 1990-March 1993. 

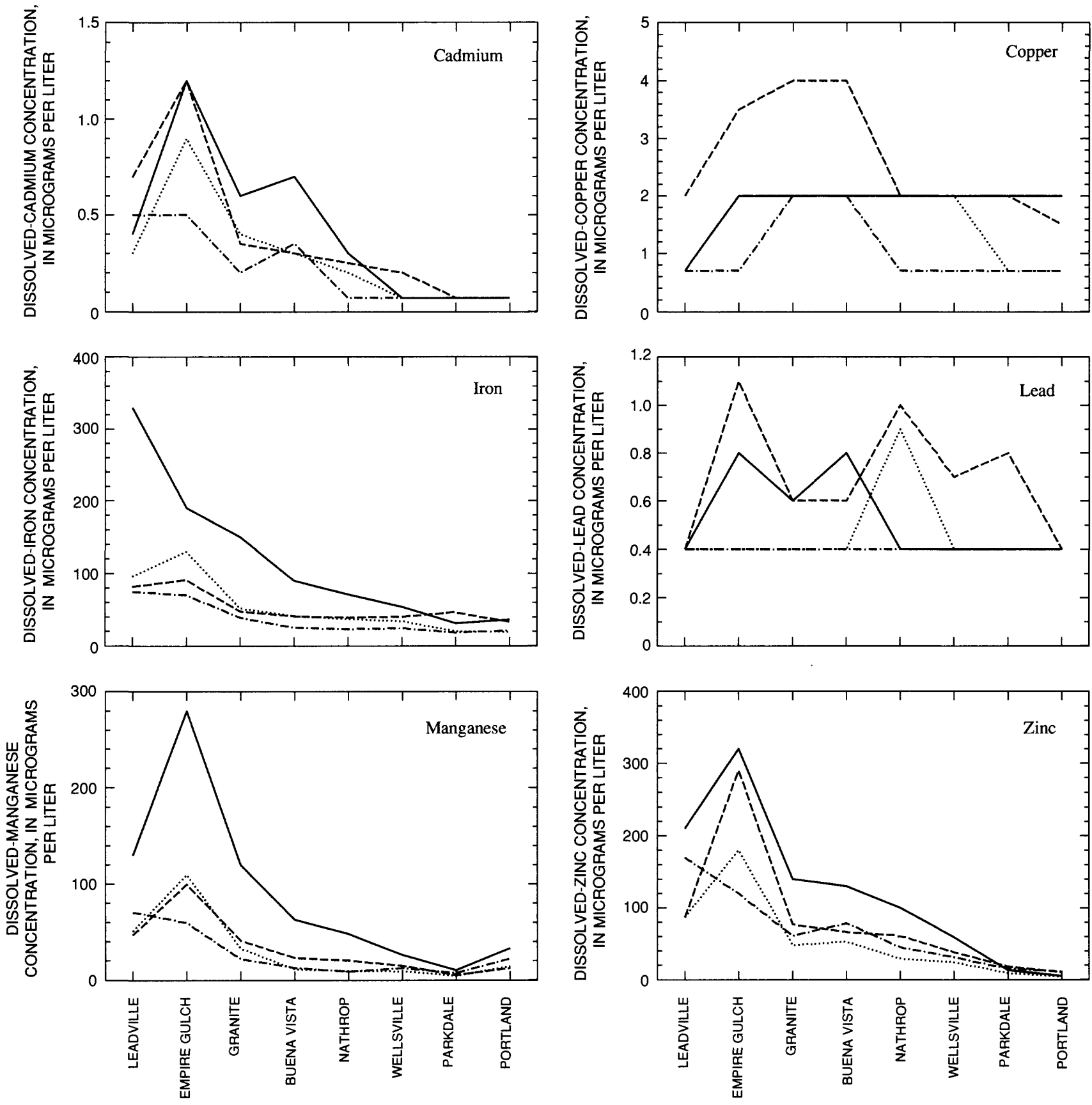

\section{EXPLANATION}

- EARLY-SNOWMELT RUNOFF

----. PEAK-SNOWMELT RUNOFF

........... POST-SNOWMELT RUNOFF

-..... LOW FLOW

Figure 5. Median concentrations of dissolved metals by sampling site and streamflow regime, April 1990-March 1993. 
Table 2. Statistical summary of total-recoverable and dissolved-metal concentrations in the upper Arkansas River, April 1990 through March 1993

$[\mu \mathrm{g} / \mathrm{L}$, micrograms per liter; <, less than]

\begin{tabular}{|c|c|c|c|c|c|c|c|}
\hline $\begin{array}{l}\text { Site name } \\
\text { (see table 1) }\end{array}$ & $\begin{array}{c}\text { Number } \\
\text { of } \\
\text { samples }\end{array}$ & $\begin{array}{c}\text { Minimum } \\
\text { reporting } \\
\text { level } \\
(\mu \mathrm{g} / \mathrm{L})\end{array}$ & $\begin{array}{c}\text { Number of } \\
\text { samples less } \\
\text { than reporting } \\
\text { level }\end{array}$ & $\begin{array}{l}\text { Mean'1 } \\
(\mu g / L)\end{array}$ & $\begin{array}{c}\operatorname{Median}^{1} \\
(\mu \mathrm{g} / \mathrm{L})\end{array}$ & $\begin{array}{c}\text { Minimum } \\
(\mu \mathrm{g} / \mathrm{L})\end{array}$ & $\begin{array}{c}\text { Maximum } \\
(\mu \mathrm{g} / \mathrm{L})\end{array}$ \\
\hline \multicolumn{8}{|c|}{ Total-recoverable cadmium } \\
\hline Leadville & 26 & 1 & 18 & 0.9 & 0.7 & $<1$ & 2 \\
\hline Empire Gulch & 26 & 1 & 8 & 1.6 & 1 & $<1$ & 5 \\
\hline Granite & 26 & 1 & 19 & 1 & .7 & $<1$ & 4 \\
\hline Buena Vista & 26 & 1 & 21 & 1.1 & .7 & $<1$ & 5 \\
\hline Nathrop & 25 & 1 & 17 & 1.1 & .7 & $<1$ & 4 \\
\hline Wellsville & 26 & 1 & 21 & 1.3 & .7 & $<1$ & 9 \\
\hline Parkdale & 26 & 1 & 19 & 1.7 & .7 & $<1$ & 14 \\
\hline Portland & 26 & 1 & 21 & 1.1 & .7 & $<1$ & 5 \\
\hline \multicolumn{8}{|c|}{ Dissolved cadmium } \\
\hline Leadville & 26 & 0.1 & 0 & .51 & .4 & 0.1 & 1.6 \\
\hline Empire Gulch & 26 & .1 & 0 & .91 & .9 & .1 & 1.9 \\
\hline Granite & 26 & .1 & 2 & .42 & .4 & $<.1$ & 2 \\
\hline Buena Vista & 26 & .1 & 0 & .4 & .3 & .1 & 1.2 \\
\hline Nathrop & 25 & .1 & 3 & .22 & .2 & $<.1$ & 0.6 \\
\hline Wellsville & 26 & .1 & 8 & .16 & .1 & $<.1$ & .6 \\
\hline Parkdale & 26 & .1 & 22 & .10 & .07 & $<.1$ & .4 \\
\hline Portland & 26 & .1 & 19 & .10 & .07 & $<.1$ & .4 \\
\hline \multicolumn{8}{|c|}{ Total-recoverable copper } \\
\hline Leadville & 23 & 1 & 4 & 2.7 & 2 & $<1$ & 9 \\
\hline Empire Gulch & 24 & 1 & 0 & 5.4 & 4 & 1 & 17 \\
\hline Granite & 21 & 1 & 1 & 5.3 & 4 & $<1$ & 17 \\
\hline Buena Vista & 20 & 1 & 3 & 3.6 & 3 & $<1$ & 9 \\
\hline Nathrop & 21 & 1 & 3 & 5.3 & 4 & $<1$ & 26 \\
\hline Wellsville & 21 & 1 & 0 & 4.2 & 3 & 1 & 10 \\
\hline Parkdale & 20 & 1 & 2 & 6.5 & 3.5 & $<1$ & 45 \\
\hline Portland & 20 & 1 & 0 & 6.6 & 4 & 2 & 34 \\
\hline \multicolumn{8}{|c|}{ Dissolved copper } \\
\hline Leadville & 24 & 1 & 10 & 1.2 & 1 & $<1$ & 3 \\
\hline Empire Gulch & 24 & 1 & 3 & 2.4 & 2 & $<1$ & 9 \\
\hline Granite & 22 & 1 & 1 & 2.3 & 2 & $<1$ & 5 \\
\hline Buena Vista & 22 & 1 & 2 & 2.7 & 2 & $<1$ & 13 \\
\hline Nathrop & 21 & 1 & 3 & 1.9 & 2 & $<1$ & 7 \\
\hline Wellsville & 22 & 1 & 1 & 1.8 & 2 & $<1$ & 3 \\
\hline Parkdale & 22 & 1 & 1 & 3 & 1.5 & 1 & $<1$ \\
\hline Portland & 20 & 1 & 3 & 1.3 & 1 & $<1$ & 3 \\
\hline \multicolumn{8}{|c|}{ Total-recoverable iron } \\
\hline Leadville & 26 & 10 & 0 & 440 & 235 & 120 & 2,300 \\
\hline Empire Gulch & 26 & 10 & 0 & 630 & 425 & 180 & 3,200 \\
\hline Granite & 26 & 10 & 0 & 511 & 255 & 110 & 3,300 \\
\hline Buena Vista & 26 & 10 & 0 & 619 & 190 & 60 & 6,900 \\
\hline Nathrop & 25 & 10 & 0 & 808 & 260 & 60 & 7,300 \\
\hline Wellsville & 26 & 10 & 0 & 895 & 215 & 90 & 8,000 \\
\hline Parkdale & 26 & 10 & 0 & 2,661 & 420 & 30 & 27,000 \\
\hline Portland & 26 & 10 & 0 & 3,525 & 935 & 180 & 25,000 \\
\hline
\end{tabular}


Table 2. Statistical summary of total-recoverable and dissolved-metal concentrations in the upper Arkansas River, April 1990 through March 1993-Continued

$[\mu \mathrm{g} / \mathrm{L}$, micrograms per liter; $<$, less than]

\begin{tabular}{|c|c|c|c|c|c|c|c|}
\hline $\begin{array}{l}\text { Site name } \\
\text { (see table 1) }\end{array}$ & $\begin{array}{c}\text { Number } \\
\text { of } \\
\text { samples }\end{array}$ & $\begin{array}{c}\text { Minimum } \\
\text { reporting } \\
\text { level } \\
(\mu \mathrm{g} / \mathrm{L})\end{array}$ & $\begin{array}{c}\text { Number of } \\
\text { samples less } \\
\text { than reporting } \\
\text { level }\end{array}$ & $\begin{array}{l}\operatorname{Mean}^{1} \\
(\mu \mathrm{g} / \mathrm{L})\end{array}$ & $\begin{array}{c}\text { Median } 1 \\
(\mu \mathrm{g} / \mathrm{L})\end{array}$ & $\underset{(\mu \mathrm{g} / \mathrm{L})}{\operatorname{Minimum}}$ & $\underset{(\mu \mathrm{g} / L)}{\operatorname{Maximum}}$ \\
\hline \multicolumn{8}{|c|}{ Dissolved iron } \\
\hline Leadville & 26 & 3 & 0 & 126 & 88 & 25 & 710 \\
\hline Empire Gulch & 26 & 3 & 0 & 121 & 92 & 60 & 440 \\
\hline Granite & 26 & 3 & 0 & 76 & 51 & 21 & 570 \\
\hline Buena Vista & 26 & 3 & 0 & 47 & 39 & 20 & 180 \\
\hline Nathrop & 25 & 3 & 0 & 43 & 34 & 15 & 130 \\
\hline Wellsville & 26 & 3 & 0 & 36 & 34 & 18 & 70 \\
\hline Parkdale & 26 & 3 & 0 & 26 & 20 & 15 & 53 \\
\hline Portland & 26 & 3 & 0 & 24 & 21 & 10 & 54 \\
\hline \multicolumn{8}{|c|}{ Total-recoverable lead } \\
\hline Leadville & 26 & 1 & 5 & 7.1 & 2.5 & $<1$ & 110 \\
\hline Empire Gulch & 26 & 1 & 1 & 13.5 & 8.5 & $<1$ & 80 \\
\hline Granite & 26 & 1 & 1 & 12.4 & 7 & $<1$ & 72 \\
\hline Buena Vista & 26 & 1 & 2 & 15.1 & 5 & $<1$ & 110 \\
\hline Nathrop & 25 & 1 & 2 & 18.1 & 6 & $<1$ & 85 \\
\hline Wellsville & 26 & 1 & 2 & 11.8 & 3.5 & $<1$ & 92 \\
\hline Parkdale & 26 & 1 & 4 & 13.8 & 3 & $<1$ & 120 \\
\hline Portland & 26 & 1 & 1 & 14.3 & 4.5 & $<1$ & 110 \\
\hline \multicolumn{8}{|c|}{ Dissolved lead } \\
\hline Leadville & 26 & 0.5 & 19 & 0.56 & 0.3 & $<0.5$ & 4.8 \\
\hline Empire Gulch & 26 & .5 & 12 & 0.68 & 0.5 & $<0.5$ & 2 \\
\hline Granite & 26 & .5 & 14 & 1.3 & 0.3 & $<0.5$ & 14 \\
\hline Buena Vista & 26 & .5 & 15 & 0.81 & 0.3 & $<0.5$ & 6.8 \\
\hline Nathrop & 25 & .5 & 12 & 2.3 & 0.6 & $<0.5$ & 26 \\
\hline Wellsville & 26 & .5 & 18 & 0.48 & 0.3 & $<0.5$ & 1.5 \\
\hline Parkdale & 26 & .5 & 18 & 0.50 & 0.3 & $<0.5$ & 1.6 \\
\hline Portland & 26 & .5 & 15 & 0.53 & 0.3 & $<0.5$ & 1.4 \\
\hline \multicolumn{8}{|c|}{ Total-recoverable manganese } \\
\hline Leadville & 26 & 10 & 1 & 102 & 75 & $<10$ & 300 \\
\hline Empire Gulch & 26 & 10 & 0 & 192 & 150 & 50 & 580 \\
\hline Granite & 26 & 10 & 0 & 108 & 60 & 30 & 640 \\
\hline Buena Vista & 26 & 10 & 1 & 101 & 40 & $<10$ & 750 \\
\hline Nathrop & 25 & 10 & 1 & 100 & 40 & $<10$ & 580 \\
\hline Wellsville & 26 & 10 & 1 & 96 & 40 & $<10$ & 610 \\
\hline Parkdale & 26 & 10 & 2 & 167 & 40 & $<10$ & 1,300 \\
\hline Portland & 26 & 10 & 0 & 175 & 70 & 15 & 990 \\
\hline \multicolumn{8}{|c|}{ Dissolved manganese } \\
\hline Leadville & 26 & 1 & 0 & 69 & 49 & 14 & 230 \\
\hline Empire Gulch & 26 & 1 & 0 & 129 & 100 & 24 & 480 \\
\hline Granite & 26 & 1 & 0 & 54 & 24 & 12 & 500 \\
\hline Buena Vista & 26 & 1 & 0 & 26 & 14 & 7 & 130 \\
\hline Nathrop & 25 & 1 & 0 & 18 & 10 & 6 & 73 \\
\hline Wellsville & 26 & 1 & 0 & 15 & 12 & 7 & 39 \\
\hline Parkdale & 26 & 1 & 0 & 6.2 & 5 & 2 & 12 \\
\hline Portland & 26 & 1 & 0 & 18 & 17 & 7 & 34 \\
\hline
\end{tabular}


Table 2. Statistical summary of total-recoverable and dissolved-metal concentrations in the upper Arkansas River, April 1990 through March 1993—Continued

$[\mu \mathrm{g} / \mathrm{L}$, micrograms per liter; $<$, less than $]$

\begin{tabular}{|c|c|c|c|c|c|c|c|}
\hline $\begin{array}{c}\text { Site name } \\
\text { (see table 1) }\end{array}$ & $\begin{array}{l}\text { Number } \\
\text { of } \\
\text { samples }\end{array}$ & $\begin{array}{c}\text { Minimum } \\
\text { reporting } \\
\text { level } \\
(\mu \mathrm{g} / L)\end{array}$ & $\begin{array}{c}\text { Number of } \\
\text { samples less } \\
\text { than reporting } \\
\text { level }\end{array}$ & $\begin{array}{l}\text { Mean }^{1} \\
(\mu \mathrm{g} / \mathrm{L})\end{array}$ & $\begin{array}{c}\text { Median }^{1} \\
(\mu \mathrm{g} / \mathrm{L})\end{array}$ & $\begin{array}{c}\text { Minimum } \\
(\mu \mathrm{g} / \mathrm{L})\end{array}$ & $\begin{array}{c}\text { Maximum } \\
(\mu \mathrm{g} / L)\end{array}$ \\
\hline \multicolumn{8}{|c|}{ Total-recoverable zinc } \\
\hline Leadville & 26 & 10 & 0 & 162 & 120 & 20 & 440 \\
\hline Empire Gulch & 26 & 10 & 0 & 305 & 240 & 70 & 890 \\
\hline Granite & 26 & 10 & 0 & 197 & 105 & 40 & 1,000 \\
\hline Buena Vista & 26 & 10 & 0 & 169 & 115 & 40 & 840 \\
\hline Nathrop & 25 & 10 & 0 & 149 & 80 & 30 & 670 \\
\hline Wellsville & 26 & 10 & 0 & 118 & 60 & 20 & 800 \\
\hline Parkdale & 26 & 10 & 1 & 128 & 50 & $<10$ & 820 \\
\hline Portland & 26 & 10 & 1 & 118 & 45 & $<10$ & 790 \\
\hline \multicolumn{8}{|c|}{ Dissolved zinc } \\
\hline Leadville & 26 & 3 & 0 & 133 & 87 & 16 & 370 \\
\hline Empire Gulch & 26 & 3 & 0 & 206 & 180 & 45 & 530 \\
\hline Granite & 26 & 3 & 0 & 94 & 61 & 24 & 620 \\
\hline Buena Vista & 26 & 3 & 0 & 89 & 76 & 30 & 200 \\
\hline Nathrop & 25 & 3 & 0 & 55 & 49 & 23 & 190 \\
\hline Wellsville & 26 & 3 & 0 & 33 & 31 & 4 & 73 \\
\hline Parkdale & 26 & 3 & 0 & 15 & 12 & $<3$ & 33 \\
\hline Portland & 26 & 3 & 3 & 8.7 & 7 & 2 & 25 \\
\hline
\end{tabular}

${ }^{1}$ Metal concentrations less than the reporting level were assigned values of two-thirds times the reporting level for the purpose of estimating the mean and median concentrations. 
early-snowmelt runoff. During early-snowmelt runoff, streamflow begins to increase, as lower elevation snow melts and flushes the abandoned mines, mine dumps, and tailings piles of metalenriched water. The volume of water that actually flows into the river during the early-snowmelt season is relatively small, but because flow in the river also is small, the effect on metal concentrations can be substantial. Dissolved-iron concentrations exhibited the same general patterns as dissolved cadmium, manganese, and zinc except the elevated concentrations at Empire Gulch were not observed during earlysnowmelt runoff, and partitioning to the particulate phase downstream, especially during peak-snowmelt runoff, was more substantial for iron.

The spatial and temporal patterns displayed in the dissolved-copper and dissolved-lead concentration plots are quite different from those for the other metals (fig. 5). The spatial and temporal distributions of dissolved-copper and dissolved-lead concentrations are partly attributable to the large number of samples that had concentrations of dissolved copper and dissolved lead that were less than or near the laboratory reporting levels. Dissolved-copper and dissolved-lead concentrations increased between Leadville and Empire Gulch and then remained somewhat elevated downstream to about Nathrop. Dissolved-copper and dissolved-lead concentrations tended to be highest during peak-snowmelt runoff (fig. 5). Dissolved-metal concentrations generally are expected to become diluted with increasing discharge. The elevated dissolved-copper and dissolved-lead concentrations might be an artifact of filtration; during the peak-snowmelt flow regime, resuspension of colloidal-sized material increases, some of which may pass through the $0.45-\mu \mathrm{m}$ filters, resulting in increased "dissolved" concentrations in the environmental samples (Kimball and others, 1995).

\section{MODEL RESULTS OF METAL SPECIATION}

The geochemical speciation model, MINTEQA2, was used to estimate the temporal and spatial distributions of dissolved cadmium, copper, lead, and zinc species. Generally, the free-metal ions are the most bioavailable and toxic species because they can be taken directly from the water column by aquatic life (Gerhardt, 1993; Borgmann, 1983); complexed forms of metals are less toxic because the metals are bound to ligands. In the upper Arkansas River, the potential for metal complexation varies temporally and spatially, owing to the effect of stream flow regime on water chemistry. Therefore, metal bioavailability and toxicity to aquatic life is a function of dissolved-metal concentration and streamflow regime.

The metal species calculated for the water samples collected from the Arkansas River include the free-metal ions, hydroxide complexes, sulfate complexes, carbonate complexes, and chloride complexes. The dominant species (greater than 1 percent of dissolved-metal concentration) calculated for each metal are listed in table 3 . The results of the speciation modeling are summarized in the following sections by sampling site and streamflow regime in terms of the median dissolved-metal species concentrations. The spatial and temporal patterns in the dissolved-metal species concentrations in the individual model runs were very consistent; therefore, the median species concentrations adequately represent the dominant speciation patterns.

Table 3. Model-calculated dissolved-metal species listed in descending order of predominance

\begin{tabular}{llll}
\hline \multicolumn{1}{c}{ Cadmium } & \multicolumn{1}{c}{ Copper } & \multicolumn{1}{c}{ Lead } & \multicolumn{1}{c}{ Zinc } \\
\hline $\mathrm{Cd}^{+2}$ & $\mathrm{Cu}(\mathrm{OH})_{2}$ & $\mathrm{PbCO}_{3}$ & $\mathrm{Zn}^{+2}$ \\
$\mathrm{CdCO}_{3}$ & $\mathrm{CuCO}$ & $\mathrm{PbOH}_{3}$ & $\mathrm{ZnCO}$ \\
$\mathrm{CdHCO}_{3}{ }^{+}$ & $\mathrm{Cu}^{+2}$ & $\mathrm{~Pb}\left(\mathrm{CO}_{3}\right)_{2}{ }^{-2}$ & $\mathrm{Zn}(\mathrm{OH})_{2}$ \\
$\mathrm{CdSO}_{4}$ & $\mathrm{CuOH}^{+}$ & $\mathrm{Pb}^{+2}$ & $\mathrm{Zn}\left(\mathrm{CO}_{3}\right)_{2}{ }^{-2}$ \\
$\mathrm{CdCl}^{+}$ & $\mathrm{CuHCO}_{3}{ }^{+}$ & $\mathrm{PbHCO}_{3}{ }^{+}$ & $\mathrm{ZnHCO}_{3}{ }^{+}$ \\
& & $\mathrm{PbSO}_{4}$ & $\mathrm{ZnOH}^{+}$ \\
& & $\mathrm{Pb}(\mathrm{OH})_{2}$ & $\mathrm{ZnSO}_{4}$ \\
\hline
\end{tabular}

\section{Cadmium}

The model-calculated dissolved-cadmium speciation was dominated by the free-metal ion $\left(\mathrm{Cd}^{+2}\right)$ and the carbonate species $\left(\mathrm{CdCO}_{3}\right)$. The dissolvedcadmium species varied spatially (fig. 6). The highest median concentrations of $\mathrm{Cd}^{+2}$ were calculated for samples collected at the Empire Gulch site and tended to decrease downstream to Portland, where the lowest median concentration was calculated for $\mathrm{Cd}^{+2}$. The 

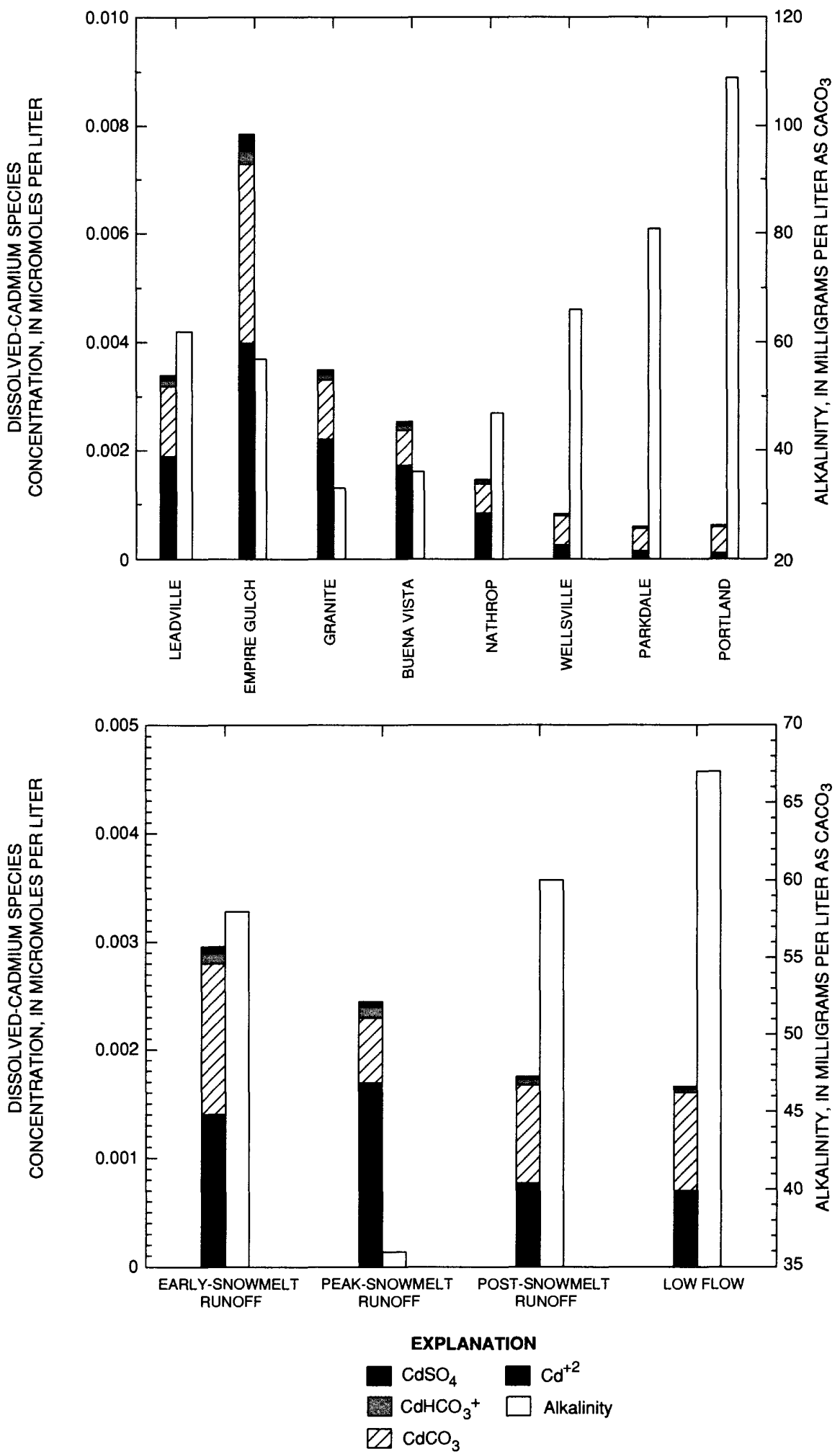

Figure 6. Median concentrations of dissolved-cadmium species and alkalinity by sampling site and streamflow regime, April 1990-March 1993. 
$\mathrm{Cd}^{+2}$ species accounted for about one-half of the dissolved-cadmium species present at Leadville (55 percent), Empire Gulch (49 percent), Granite (63 percent), Buena Vista (68 percent), and Nathrop (57 percent). The $\mathrm{Cd}^{+2}$ species accounted for less than one-half of the dissolved-cadmium species present at Wellsville (31 percent), Parkdale (25 percent), and Portland (18 percent). Although the concentration of $\mathrm{Cd}^{+2}$ decreased downstream from Empire Gulch, the percentage of the dissolved-cadmium concentration represented by $\mathrm{Cd}^{+2}$ increased at Granite and Buena Vista. The degree of cadmium complexation increased downstream from Buena Vista to a maximum of about 80 percent of the dissolvedcadmium species at Portland.

Temporally, the highest median concentration of $\mathrm{Cd}^{+2}$ was calculated during the early-snowmelt and peak-snowmelt runoff periods (fig. 6). Lower median concentrations of $\mathrm{Cd}^{+2}$ were calculated during the post-snowmelt and low-flow periods. On average, about 72 percent of the dissolved-cadmium species was calculated to be $\mathrm{Cd}^{+2}$ during the peak-snowmelt runoff period. About 58 percent of the dissolved cadmium was calculated to occur as complexed species during the post-snowmelt and low-flow periods.

The U.S. Fish and Wildlife Service (1993) expressed concern that metal toxicity to aquatic life might be increased by the inflow of low ionic-strength water from Lake Creek. The model results indicated that a higher percentage of dissolved cadmium occurred as $\mathrm{Cd}^{+2}$ from the Lake Creek confluence downstream to Buena Vista. Although the percentage of the dissolved cadmium represented by $\mathrm{Cd}^{+2}$ increased downstream from Lake Creek, the concentration of $\mathrm{Cd}^{+2}$ and the cadmium complexes generally decreased in the reach because of dilution by Lake Creek and increased partitioning of cadmium to the particulate phase. The median dissolved-cadmium concentration, expressed as a percentage of the totalrecoverable cadmium concentration, decreased from 55 percent at Empire Gulch to 32 percent at Granite and decreased steadily downstream to Portland. The relation between an increase in the percentage of dissolved cadmium represented by $\mathrm{Cd}^{+2}$ and a decrease in the $\mathrm{Cd}^{+2}$ concentrations varied temporally. During the low-flow period, the measured concentration of dissolved cadmium decreased downstream between Empire Gulch and Buena Vista; however, the model results indicated that in four of the nine low- flow water parcels, the concentration of $\mathrm{Cd}^{+2}$ increased in the reach. Although the $\mathrm{Cd}^{+2}$ concentration increased downstream from Lake Creek during low flow, the dissolved-cadmium concentrations were less than the chronic-toxicity standard for aquatic life (Colorado Department of Health, 1994). If it is assumed that cadmium bioavailability is proportional to the $\mathrm{Cd}^{+2}$ concentration, then during most flow regimes cadmium bioavailability decreased in the Arkansas River downstream from Lake Creek. However, there were incidences during the low-flow period when cadmium bioavailability increased downstream from Lake Creek.

\section{Copper}

Unlike the dissolved-cadmium species, which existed primarily as its free-metal ion, the model results indicate that most dissolved copper existed as copper complexes (fig. 7). The copper-hydroxide species, $\mathrm{Cu}(\mathrm{OH})_{2}$, accounted for more than 90 percent of the dissolved copper at all sites and all flow regimes. $\mathrm{Cu}^{+2}$ accounted for less than 2 percent of the dissolved-copper species in all samples collected from the eight Arkansas River sites. The median concentrations of the dissolved-copper species were not spatially variable in the reach from Empire Gulch to Wellsville (fig. 7). Likewise, there is little variability between the median concentrations of $\mathrm{Cu}(\mathrm{OH})_{2}$, $\mathrm{CuCO}_{3}$, and $\mathrm{Cu}^{+2}$ that were calculated for early-, peak-, and post-snowmelt runoff. The lowest median concentrations were calculated during the low-flow period (fig. 7). Assuming that copper bioavailability is proportional to the $\mathrm{Cu}^{+2}$ concentration, then most dissolved copper was not readily bioavailable and was not strongly affected by location within the basin or by streamflow regime.

\section{Lead}

Of the four metals that were modeled, lead exhibited the highest affinity for complexing with the carbonate ligand. Model results indicate that more than 90 percent of the dissolved lead was complexed as the $\mathrm{PbCO}_{3}$ species at all locations and during all flow regimes (fig. 8). The spatial pattern for dissolved-lead species (fig. 8) is the result of the large number of samples that had concentrations less than or 

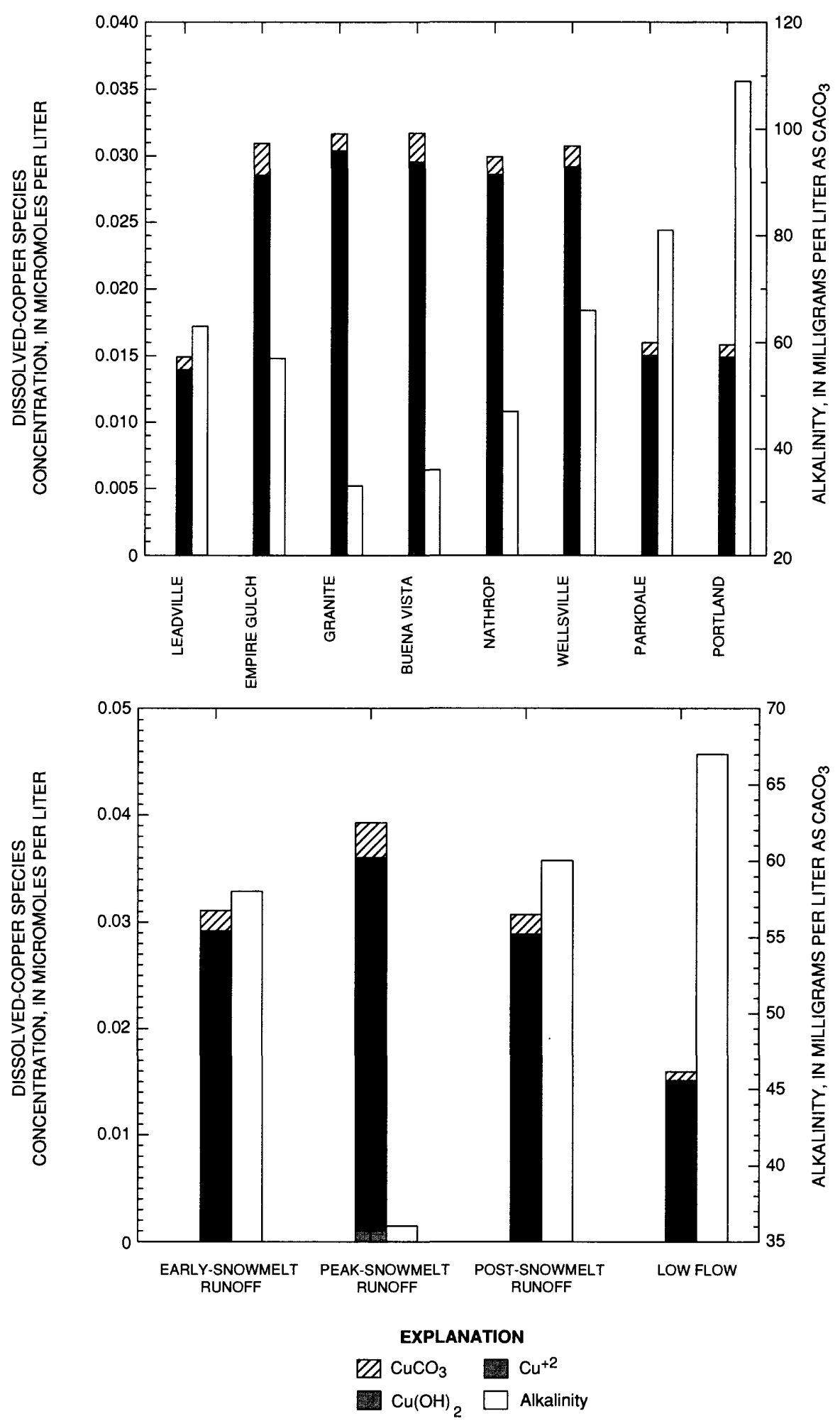

Figure 7. Median concentrations of dissolved-copper species and alkalinity by sampling site and streamflow regime, April 1990-March 1993. 

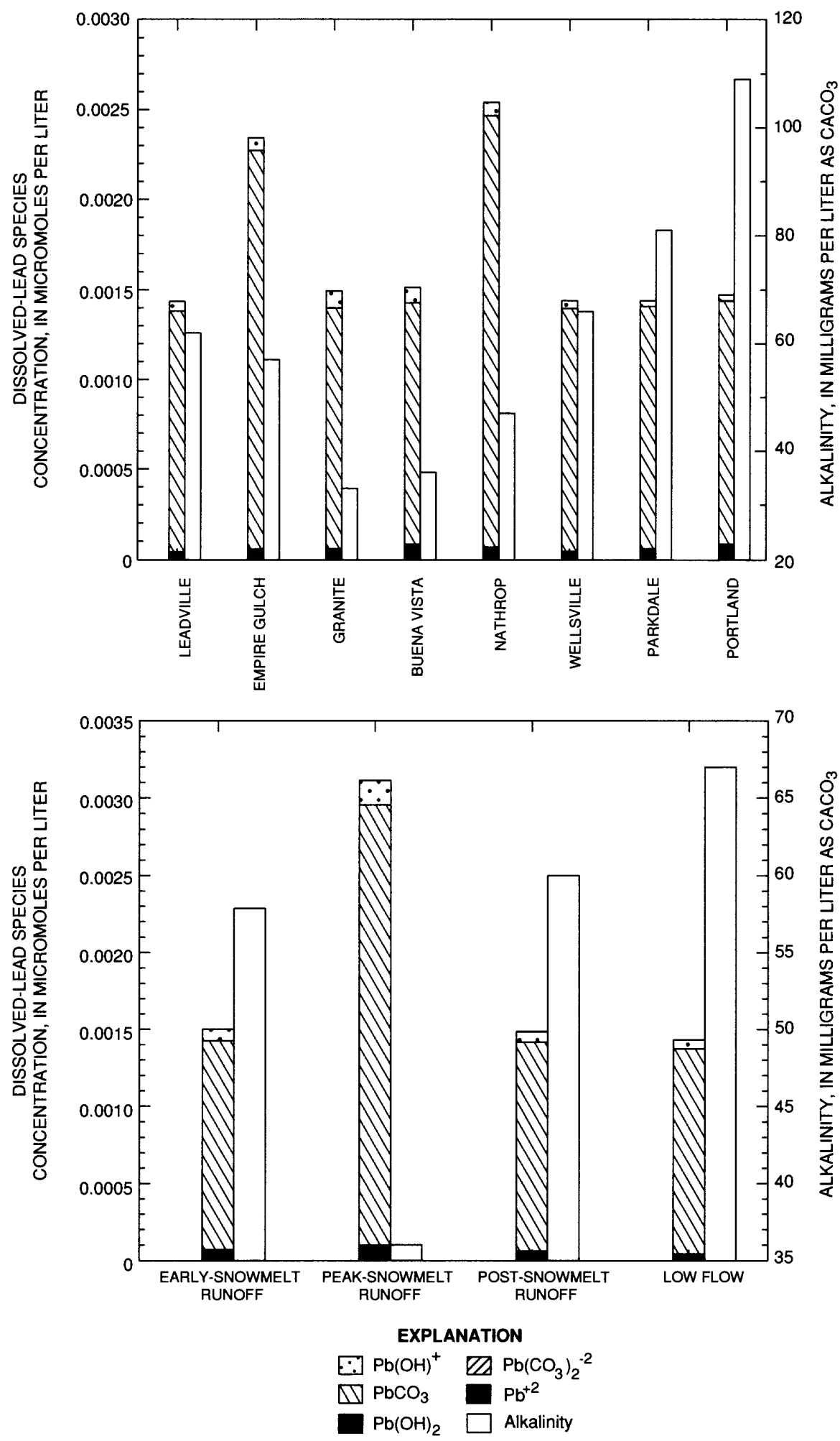

Figure 8. Median concentrations of dissolved-lead species and alkalinity by sampling site and streamflow regime, April 1990-March 1993. 
near the laboratory's minimum reporting level for dissolved lead (table 2). The maximum calculated $\mathrm{Pb}^{+2}$ concentration represented 19 percent of the dissolved lead in a sample collected at Buena Vista during peak-snowmelt runoff, although the average $\mathrm{Pb}^{+2}$ concentration at Buena Vista represented only 5 percent of the dissolved lead. The maximum $\mathrm{Pb}^{+2}$ and $\mathrm{PbCO}_{3}$ concentrations were calculated for samples collected during peak-snowmelt runoff. During peak-snowmelt runoff, $\mathrm{Pb}^{+2}$ accounted for about 3 percent of the dissolved-lead species at most sites. Assuming that lead bioavailability is proportional to the $\mathrm{Pb}^{+2}$ concentration, then most dissolved lead, like copper, was not readily bioavailable and was not strongly affected by location within the basin or by streamflow regime.

\section{Zinc}

Like cadmium, the dominant dissolved-zinc species were the free-metal ion $\left(\mathrm{Zn}^{+2}\right)$ and the carbonate $\left(\mathrm{ZnCO}_{3}\right)$ species (fig. 9). Unlike cadmium, zinc hydrolyzes at a lower $\mathrm{pH}$; therefore, hydroxide species were calculated to occur for zinc. The highest median concentrations of $\mathrm{Zn}^{+2}, \mathrm{ZnCO}_{3}$, and $\mathrm{Zn}(\mathrm{OH})_{2}$ were calculated for samples collected from the Empire Gulch site (fig. 9). Although the median concentrations of $\mathrm{Zn}^{+2}, \mathrm{ZnCO}_{3}$, and $\mathrm{Zn}(\mathrm{OH})_{2}$ tended to decrease downstream from Empire Gulch, the percentage of dissolved zinc represented by $\mathrm{Zn}^{+2}$ tended to increase at several downstream sites. The $\mathrm{Zn}^{+2}$ species accounted for more than one-half of the dissolved-zinc species at Leadville (55 percent), Empire Gulch (52 percent), Granite (59 percent), Buena Vista (70 percent), and Nathrop (52 percent). The $\mathrm{Zn}^{+2}$ species accounted for less than one-half of the dissolved-zinc species at Wellsville (40 percent), Parkdale (17 percent), and Portland (14 percent). Low complexing capabilities of water input from Lake Creek, in addition to a lower median $\mathrm{pH}$ than for the other main-stem sites, contributed to the dominance of the $\mathrm{Zn}^{+2}$ species at Buena Vista. Downstream from Nathrop, zinc complexes were more common than $\mathrm{Zn}^{+2}$. On average, about 80 percent of the dissolved zinc was calculated to occur as complexed species at Portland.

The highest median concentrations for $\mathrm{Zn}^{+2}$, $\mathrm{ZnCO}_{3}$, and $\mathrm{Zn}(\mathrm{OH})_{2}$ were calculated for samples collected during early-snowmelt runoff, although the peak-snowmelt runoff samples had the highest percentage ( 70 percent) of $\mathrm{Zn}^{+2}$, expressed as a fraction of the dissolved-zinc concentration (fig. 9). Low complexing capabilities of water during peaksnowmelt runoff, in addition to a lower median $\mathrm{pH}$ than for the other flow regimes, contributed to the dominance of $\mathrm{Zn}^{+2}$ during peak-snowmelt runoff. During early-snowmelt runoff, dissolved-zinc concentrations were higher, but alkalinity and $\mathrm{pH}$ also were higher. Thus, more dissolved zinc was complexed. About 58 percent of the dissolved zinc was calculated to occur as complexed species during low-flow conditions when alkalinity and $\mathrm{pH}$ values generally were highest.

As in the case of cadmium, the free-metal ion and complexed zinc species concentrations generally decreased downstream from Lake Creek, largely because of dilution. However, in two of the nine lowflow water parcels sampled, the calculated concentrations of $\mathrm{Zn}^{+2}$ increased downstream from Lake Creek, although dissolved-zinc concentrations were less than the chronic-toxicity standard for aquatic life (Colorado Department of Health, 1994). Assuming that zinc bioavailability is proportional to the $\mathrm{Zn}^{+2}$ concentration, then during most flow regimes, zinc bioavailability decreased in the Arkansas River downstream from Lake Creek because of dilution. However, there were incidences during low flow when the bioavailability increased downstream from Lake Creek.

\section{Sensitivity Analysis}

Sensitivity testing of the model was done to determine the effects of modeling assumptions on cadmium, copper, lead, and zinc speciation results. Dissolved iron was assumed to exist as Fe(III), on the basis of the high dissolved-oxygen concentrations. However, previous studies have indicated that $\mathrm{Fe}$ (II) and $\mathrm{Fe}(\mathrm{III})$ are present in the dissolved phase of the Arkansas River (Kimball and others, 1995).

Sensitivity tests were run with dissolved iron entered in several oxidation states. Speciation of cadmium, copper, lead, and zinc was insensitive to the changes in the oxidation state of iron. Another assumption that was made in the modeling was that ferrihydrite $\left[\mathrm{Fe}(\mathrm{OH})_{3}\right]$ was allowed to precipitate from solution. Sensitivity tests were run where ferrihydrite was not 

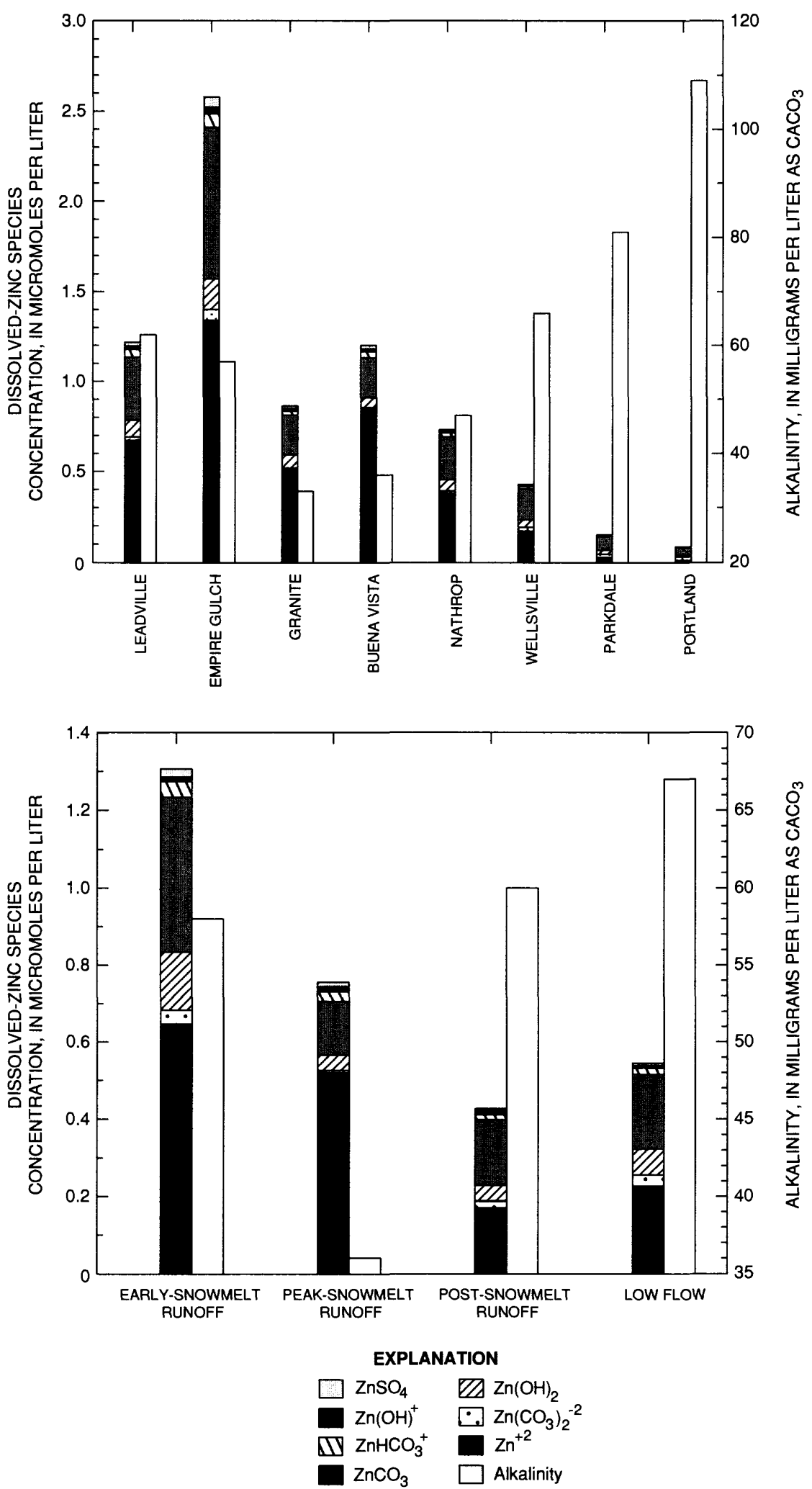

Figure 9. Median concentrations of dissolved-zinc species and alkalinity by sampling site and streamflow regime, April 1990-March 1993. 
allowed to precipitate. The results of this testing indicated again that the concentrations calculated for species of cadmium, copper, lead, and zinc were not sensitive to the solid phase defined for iron.

For this study, the dissolved phase was operationally defined as water passing through a $0.45-\mu \mathrm{m}$ filter. However, previous studies have indicated that some of the dissolved iron passing through a $0.45-\mu \mathrm{m}$ filter exists in the colloidal form (Kimball and others, 1995). To determine the effect of adsorption on the concentrations calculated for species of cadmium, copper, lead, and zinc, a diffuse doublelayer adsorption model was specified for reactions involving colloidal ferrihydrite. The amorphous structure of ferrihydrite creates a large surface area for binding sites. The estimated surface area specified in the modeling was $600 \mathrm{~m}^{2} / \mathrm{g}$ of ferrihydrite (Dzombak and Morel, 1990). Surface densities for sorption sites on ferrihydrite were divided into two types: (1) type-1 sites correspond to high-affinity cation-binding sites, and (2) type-2 sites correspond to total-reactive sites available for sorption of cations, anions, and protons. The site densities for type- 1 and type- 2 sites are based on empirical data and were assumed to be $0.005 \mathrm{~mole} / \mathrm{mole}$ of iron and $0.23 \mathrm{~mole} / \mathrm{mole}$ of iron, respectively (Dzombak and Morel, 1990). A range of iron concentrations was tested to determine the effects of the adsorption on the concentrations calculated for species of cadmium, copper, lead, and zinc when high concentrations $(700 \mu \mathrm{g} / \mathrm{L})$ of dissolved iron were present and when low concentrations $(25 \mu \mathrm{g} / \mathrm{L})$ of dissolved iron were present. The order for adsorption of dissolved metals to colloidal ferrihydrite, from highest to lowest, was lead, copper, zinc, and cadmium.

Lead and copper speciation was most sensitive to the addition of the adsorption model. For samples with high concentrations of dissolved iron, the model calculated that as much as 75 percent of the dissolved lead and 20 percent of the dissolved copper were sorbed. For samples with low concentrations of dissolved iron, about 40 percent of the dissolved lead and about 10 percent of the copper were sorbed. The sorbed lead was contributed by $\mathrm{PbCO}_{3}$ and the sorbed copper was contributed primarily by $\mathrm{Cu}(\mathrm{OH})_{2}$.

For samples with high concentrations of dissolved iron, model results indicated about 12 percent of the available zinc became bound to the ferrihydrite surfaces. About 5 percent was contributed from the $\mathrm{Zn}^{+2}$ species, and about 7 percent was contributed from the $\mathrm{ZnCO}_{3}$ and other complexed species. For samples with low concentrations of dissolved iron, the effect was negligible. For samples with high concentrations of dissolved iron, the results indicated that less than 2 percent of the available cadmium became bound to the ferrihydrite surfaces. About 1 percent was contributed from the $\mathrm{Cd}^{+2}$ species and about 1 percent was contributed from the $\mathrm{CdCO}_{3}$ species. For samples with low concentrations of dissolved iron, the effect was negligible.

The results of this testing indicate that the calculated concentrations of aqueous species represent a high estimate for the dissolved species of lead and copper, and zinc to a lesser extent. The effect of adsorption on cadmium speciation is considered negligible. Because most of the lead and copper species that were calculated to be sorbed were contributed from metal complexes, which are generally considered less toxic, the net effect of sorption on bioavailability and toxicity, with respect to the freemetal ions, probably is small. Kimball and others (1995) reported that aggregated colloids might collect toxic metals and become incorporated into the aufwuchs (biotic and abiotic material accumulating on submerged surfaces) and eventually into the food chain, thus, presenting another route for the introduction of toxic metals into the stream biota.

\section{SUMMARY AND CONCLUSIONS}

The upper Arkansas River Basin is a highaltitude, semiarid basin that extends from Leadville to Pueblo, Colorado. Water flowing through the numerous abandoned mines and tailings piles in the basin has contributed high concentrations of cadmium, copper, iron, manganese, and zinc to the Arkansas River. Metal concentrations in the river tend to vary spatially and temporally, largely owing to the effect of streamflow regime and streamflow sources. Elevated concentrations of metals in the Arkansas River are paralleled by high concentrations in the biota.

Elevated concentrations of cadmium, copper, and zinc might be one cause for an increase in the mortality rate of brown trout. The bioavailability and toxicity of metals to aquatic life vary with the dissolved-metal species. The free-metal ions, as compared to dissolved-metal complexes, are generally considered to be the more bioavailable and toxic metal species. The geochemical speciation model MINTEQA2 was 
used to evaluate the spatial and temporal variability of dissolved-metal speciation in the upper Arkansas River.

From an aquatic-life toxicity perspective, the MINTEQA2 modeling results of conditions in 1990-93 indicate that dissolved-cadmium and dissolved-zinc concentrations might represent a greater cause for concern in the upper Arkansas River than concentrations of dissolved copper and dissolved lead. At most sampling sites, more than one-half of the dissolved cadmium and dissolved zinc were calculated to occur as the more toxic free-metal ions, while less than 5 percent of the dissolved copper and lead occurred as free-metal ions. The most dominant complexed species for cadmium and zinc were the carbonates, $\mathrm{CdCO}_{3}$ and $\mathrm{ZnCO}_{3}$. Dissolved-copper and dissolved-lead complexes were dominated by $\mathrm{Cu}(\mathrm{OH})_{2}$ and $\mathrm{PbCO}_{3}$. Streamflow regime and location within the basin had little effect on the speciation of copper and lead, but cadmium speciation and zinc speciation were sensitive to both. The maximum median concentrations of dissolved $\mathrm{Cd}^{+2}$ and $\mathrm{Zn}^{+2}$ occurred at Empire Gulch. Spatially, the order of the median dissolved $\mathrm{Cd}^{+2}$ concentrations, from highest to lowest, was Empire Gulch, Granite, Leadville, Buena Vista, Nathrop, Wellsville, Parkdale, and Portland. The median dissolved $\mathrm{Zn}^{+2}$ concentrations varied spatially, from highest to lowest, in the order of Empire Gulch, Buena Vista, Leadville, Granite, Nathrop, Wellsville, Parkdale, and Portland.

Downstream from Empire Gulch, at Granite and Buena Vista, the low ionic-strength water that enters the Arkansas River from Lake Creek, in addition to poor buffering capacities of local geology, caused a higher percentage of dissolved cadmium and dissolved zinc existing as the free-metal ions. The highest percentage of dissolved cadmium and dissolved zinc represented by their free-metal ions occurred during peak-snowmelt runoff. The occurrence of $\mathrm{Cd}^{+2}$ and $\mathrm{Zn}^{+2}$ decreased substantially downstream from Buena Vista. Based on the occurrence of the median dissolved $\mathrm{Cd}^{+2}$ concentration, represented as a fraction of the median dissolved-cadmium concentration, the spatial distribution of $\mathrm{Cd}^{+2}$ concentrations was, from highest to lowest, Buena Vista, Granite, Nathrop,
Leadville, Empire Gulch, Wellsville, Parkdale, and Portland. Based on the occurrence of the median dissolved $\mathrm{Zn}^{+2}$ concentration, represented as a fraction of the median dissolved-zinc concentration, the spatial distribution of $\mathrm{Zn}^{+2}$ concentrations, from highest to lowest, was Buena Vista, Granite, Leadville, Empire Gulch, Nathrop, Wellsville, Parkdale, and Portland.

The U.S. Fish and Wildlife Service has expressed concern that metal toxicity to aquatic life, particularly from cadmium and zinc, might be increased by the inflow of low ionic-strength water from Lake Creek. The model results indicate that the Lake Creek inflow resulted in a higher percentage of the free-metal ions of cadmium and zinc (expressed as a fraction of the dissolved-metal concentration) in the reach between the inflow from Lake Creek and Buena Vista. Although the percentage of the dissolved cadmium and dissolved zinc represented by their free- metal ions increased downstream from Lake Creek, the calculated concentration of the free and complexed cadmium and zinc species generally decreased in the reach largely owing to dilution by Lake Creek. During low flow, the measured concentration of dissolved cadmium and dissolved zinc decreased downstream from Lake Creek; however, the model results indicated that in several samples the concentration of $\mathrm{Cd}^{+2}$ and $\mathrm{Zn}^{+2}$ increased. If it is assumed that cadmium and zinc bioavailability is proportional to their free-metal ion concentrations, then during most flow regimes, cadmium and zinc bioavailability decreased in the Arkansas River downstream from Lake Creek because of dilution. However, there were incidences during low flow when the bioavailability increased downstream from Lake Creek. Copper and lead exhibited similar patterns of dilution and speciation, but their free-metal ion concentrations generally were less than 5 percent of their dissolved concentrations; thus, their bioavailability was not greatly affected by differences in speciation under different streamflow regimes. 


\section{REFERENCES}

Abbott, P.O., 1985, Description of water-system operations in the Arkansas River Basin, Colorado: U.S. Geological Survey Water-Resources Investigations Report 85-4092, $67 \mathrm{p}$.

Allison, J.D., Brown, D.S., and Novo-Gradac, K.J., 1991, MINTEQA/PRODEFA2, A geochemical assessment model for environmental system-Version 3.0 user's manual: U.S. Environmental Protection Agency, EPA/600/3-91/021, 106 p.

Borgmann, U., 1983, Metal speciation and toxicity of free metal ions to aquatic biota, in Aquatic toxicology, chap. 2: New York, John Wiley and Sons, p. 47-72.

Bunting, J., 1989, A summary of the technical information related to the water quality of the upper Arkansas River Basin, in Water quality and related studies of the Upper Arkansas: Golden, Colo., February 13-14, 1989, Department of Environmental Sciences, Colorado School of Mines.

Clements, W.H., 1991, Fate and effects of heavy metals on the Arkansas River: Fort Collins, Colorado WaterResources Research Institute Completion Report no. 163,24 p.

Colorado Department of Health, 1994, Classifications and numeric standards for Arkansas River Basin, 3.2.0: Water-Quality Control Commission, Denver, Colo., $78 \mathrm{p}$.

Crouch, T.M., Cain, Douglas, Abbott, P.O., Penley, R.D., and Hurr, R.T., 1984, Water-resources appraisal of the upper Arkansas River Basin from Leadville to Pueblo, Colorado: U.S. Geological Survey Water-Resources Investigations Report 82-4114, 123 p.

Dash, R.G., and Ortiz, R.F., 1996, Selected water-quality data for the Arkansas River Basin, Colorado, 19901993: U.S. Geological Survey Open-File Report 95-464, $137 \mathrm{p}$.

Dzombak, D.A. and Morel, F.M.M., 1990, Surface complexation modeling hydrous ferric oxide, chap. 5: New York, John Wiley and Sons, p. 89-102.

Fishman, M.J., 1993, Methods of analysis by the U.S. Geological Survey National Water-Quality Laboratory-Determination of inorganic and organic constituents in water and fluvial sediments: U.S. Geological Survey Open-File Report 93-125, 217 p.

Fishman, M.J., and Friedman, L.C., eds., 1989, Methods for determination of inorganic substances in water and fluvial sediments (3d ed.): U.S. Geological Survey Techniques of Water-Resources Investigations, book 5 , chap. A1, 545 p.

Gerhardt, A., 1993, Review of impact of heavy metals on stream invertebrates with special emphasis on acid conditions: Water, Air, and Soil Pollution, v. 66, p. 289-314.
Kiffney, P.M., and Clements, W.H., 1993, Bioaccumulation of heavy metals by benthic invertebrates at the Arkansas River, Colorado: Environmental Toxicology and Chemistry, v. 12, p. 1507-1517.

Kimball, B.A., Callendar, E., and Axtmann, E.V., 1995, Effects of colloids on metal transport in a river receiving acid mine drainage, upper Arkansas River, Colorado, U.S.A.: Applied Geochemistry, v. 10, p. 285-306.

Kimball, B.A., and Wetherbee, G.A., 1989, Instream chemical reactions of acid mine water entering a neutral stream near Leadville, Colorado, in Mallard, G.E., and Ragone, S.E., eds., U.S. Geological Survey Toxic Substances Hydrology

Program-Proceedings of the technical meeting, Phoenix, Ariz., September 26-30, 1988: U.S. Geological Survey Water-Resources Investigations Report 88-4220, p. 71-79.

Lewis, M.E., and Edelmann, Patrick, 1994, Physical, chemical, and biological characteristics of Pueblo Reservoir, Colorado, 1985-89: U.S. Geological Survey Water-Resources Investigations Report $94-4097,71 \mathrm{p}$.

Moran, R.E., and Wentz, D.A., 1974, Effect of metal-mine drainage on water quality in selected areas of Colorado, 1972-1973: Denver, Colorado Water Conservation Board Water-Resource Circular no. 25, $250 \mathrm{p}$.

Nordstrom, D.K., 1991, Chemical modeling of acid mine water in the western United States, in Mallard, G.E., and Aronson, D.A., eds., U.S. Geological Survey Toxic Substances Hydrology Program-Proceedings of the technical meeting, Monterey, Calif., March 1115, 1991: U.S. Geological Survey Water-Resources Investigations Report 91-4034, p. 534-538.

Nordstrom, D.K., Plummer, L.N., Wigley, T.M.L., Wolery, T.J., Ball, J.W., Jenne, E.A., Bassett, R.L., Crerar, D.A., Florence, T.M., Fritz, B., Hoffman, M., Holdren, G.R., Jr., Lafon, G.M., Mattigod, S.V., McDuff, R.E., Morel, F., Reddy, M.M., Sposito, G., and Thrailkill, J., 1979, Chemical modeling in aqueous systems, speciation, sorption, solubility, and kinetics, in Jenne, E.A., ed., American Chemical Society Symposium Proceedings: Miami Beach, Fla, September 11-13, 1978, p. 857-892.

Ranville, J.F., Smith, K.S., Macalady, D.L., and Rees, T.F., 1989 , Colloidal properties of flocculated bed material in a stream contaminated by acid mine drainage, St. Kevin Gulch, Colorado, in Mallard, G.E., and Ragone, S.E., eds., U.S. Geological Survey Toxic Substances Hydrology Program-Proceedings of the technical meeting, Phoenix, Ariz., September 26-30, 1988: U.S. Geological Survey Water-Resources Investigations Report 88-4220, p. 111-118. 
Smith, K.S., Ranville, J.F., and Macalady, D.L., 1991, Predictive modeling of copper, cadmium, and zinc partitioning between streamwater and bed sediment from a stream receiving acid mine drainage, St. Kevin Gulch, Colorado, in Mallard, G.E., and Aronson, D.A., eds., U.S. Geological Survey Toxic Substances Hydrology Program-Proceedings of the technical meeting, Monterey, Calif., March 11-15, 1991: U.S. Geological Survey Water-Resources Investigations Report 91-4034, p. 380-386.

Stumm, W., and Morgan, J.J., 1981, Aquatic chemistry (2d ed.): New York, John Wiley and Sons, $780 \mathrm{p}$.

Sylvester, M.A., Kister, L.R., and Garret, W.B., eds., 1990, Guidelines for the collection, treatment, and analysis of water samples-U.S. Geological Survey Western Region field manual: Unpublished report on file in the Pueblo, Colo., Water-Resources Division Office of the U.S. Geological Survey, 144 p.

Tweto, Ogden, 1968, Geologic setting and interrelationships of mineral deposits in the Mountain Province of Colorado and south-central Wyoming, in Ridge, J.D., ed., Ore deposits of the United States, 1933-1967:
New York, American Institute of Mining, Metallurgical, and Petroleum Engineers, v. 1, p. 551-588.

U.S. Environmental Protection Agency, 1986, Quality criteria for water: U.S. Environmental Protection Agency, Office of Water, Washington, D.C.

U.S. Fish and Wildlife Service, 1993, Assessment of the trout population in the upper Arkansas River basin of central Colorado: U.S. Fish and Wildlife Service, Denver, Colo., $83 \mathrm{p}$.

Ward, J.R., and Harr, C.A., eds., 1990, Methods for collection and processing of surface-water and bed-material samples for physical and chemical analyses: U.S. Geological Survey Open-File Report 90-140, 71 p.

Wentz, D.A., 1974, Effect of mine drainage on the quality of streams in Colorado, 1971-1972: Denver, Colorado Conservation Board Water-Resources Circular no. 21, $115 \mathrm{p}$.

Wetherbee, G.A., Kimball, B.A., and Maura, W.S., 1991, Selected hydrologic data for the upper Arkansas River basin, Colorado, 1986-89: U.S. Geological Survey Open-File Report 91-528, 216 p. 